\title{
MUTUAL FUNDS AND INSTITUTIONAL INVESTMENTS: WHAT IS THE MOST EFFICIENT WAY TO SET UP INDIVIDUAL ACCOUNTS IN A SOCIAL SECURITY SYSTEM?
}

\author{
Estelle James \\ Gary Ferrier \\ James Smalhout \\ Dimitri Vittas
}

\author{
Working Paper 7049 \\ http://www.nber.org/papers/w7049
}

\author{
NATIONAL BUREAU OF ECONOMIC RESEARCH \\ 1050 Massachusetts Avenue \\ Cambridge, MA 02138 \\ March 1999
}

This paper was prepared for presentation at an NBER Conference on Social Security, Dec. 4, 1998. We wish to thank Deepthi Fernando and Marianne Leenaerts of the World Bank and Baglan Sultanbek of the University of Arkansas for their excellent research assistance on this project. The views expressed in this paper are those of the authors and do not reflect those of the National Bureau of Economic Research.

1999 by Estelle James, Gary Ferrier, James Smalhout, and Dimitri Vittas. All rights reserved. Short sections of text, not to exceed two paragraphs, may be quoted without explicit permission provided that full credit, including ${ }^{\circ}$ notice, is given to the source. 
Mutual Funds and Institutional Investments:

What is the Most Efficient Way to Set Up

Individual Accounts in a Social Security System?

Estelle James, Gary Ferrier,

James Smalhout, and Dimitri Vittas

NBER Working Paper No. 7049

March 1999

\section{ABSTRACT}

One of the biggest criticisms leveled at defined contribution individual account (IA) components of social security systems is that they are too expensive. This paper investigates the cost-effectiveness of three options for constructing funded social security pillars: 1) IA's invested in the retail market with relatively open choice, 2) IA's invested in the institutional market with constrained choice among investment companies, and 3) a centralized fund without individual accounts or differentiated investments across individuals. Our questions: What is the most costeffective way to organize a mandatory IA system, how does the cost of an efficient IA system compare with that of a single centralized fund, and are the cost differentials large enough to outweigh the other important considerations?

Our answers, based on empirical evidence about mutual and institutional funds in the U.S.: The retail market (option 1) allows individual investors to benefit from scale economies in asset management, but at the cost of high marketing expenses that are needed to attract and aggregate small sums of money into large pools. In contrast, a centralized fund (option 3 ) can be much cheaper because it achieves scale economies without high marketing costs, but gives workers no choice and hence is subject to political manipulation and misallocation of capital.

Mandatory IA systems can be structured to get the best of both worlds: to obtain scale economies in asset management without incurring high marketing costs or sacrificing worker choice. To accomplish this requires centralized collections, a modest level of investor service and constrained choice. The system of constrained choice described in this paper (option 2) is much cheaper than the retail market and only slightly more expensive than a single centralized fund. We estimate that it will cost only .14-.18\% of assets annually. These large administrative cost savings imply a Pareto improvement so long as choice is not constrained "too much."

Estelle James

World Bank

1818 H Street, NW

Washington, DC 20433

ejames3@worldbank.org

James Smalhout

The Hudson Institute

101518 th Street, N.W.

Suite 300

Washington, DC 20036

Smalhout@ix.netcom.com
Gary Ferrier

University of Arkansas

Department of Economics

Fayetteville, AR 72701

gferrier@comp.uark.edu

Dimitri Vittas

World Bank

1818 H Street, NW

Washington, DC 20433

dvittas@worldbank.org 


\section{Mutual Funds and Institutional Investments}

What is the Most Efficient Way to Set Up Individual Accounts in A Social Security System?

Prefunding is now seen as a desirable characteristic of old age security systems because it increases national saving, makes the financial sustainability of the system less sensitive to demographic shocks, and reduces the need to increase taxes as populations age. With prefunding comes the need to determine how the funds will be managed. Those who fear political manipulation of publicly managed funds see defined contribution individual accounts (IA's) as a way to decentralize control and thereby achieve a better allocation of the funds. But IA's have been criticized on other grounds, most important among them being high administrative costs. Costs are especially high at the start of a new system. To illustrate why administrative costs are important: an annual cost of $1 \%$ of assets (roughly equivalent to the up-front fee now charged in Chile) can reduce a worker's retirement benefits by $20 \%$, a substantial amount. Moreover, costs are more predictable than returns, and more amenable to policy choice.

This paper investigates the cost-effectiveness of three options for constructing funded social security pillars: 1) IA's invested in the retail market with relatively open choice, 2) IA's invested in the institutional market with constrained choice among investment companies, and 3) a centralized fund without individual accounts or differentiated investments across individuals. Our questions: what is the most cost-effective way to organize a mandatory IA system, how does the cost of an efficient IA system compare with that of a single centralized fund, and are the cost differentials great enough to outweigh the other important considerations? ${ }^{1}$

To answer these questions we use data from mutual funds in the U.S. because: the best data are available here; the U.S. mutual fund industry is an example of a relatively well run retail financial industry; and the U.S. is currently considering how to reform its social security system. Observing that a large institutional investment market co-exists with mutual funds in the U.S., and at much lower cost, we also use these data to quantify and identify the sources of economies from operating in the wholesale money market. Costs in both the retail and wholesale markets would be higher in developing countries, but their relative positions should be similar to those described here. This paper concentrates on countries with well functioning financial markets such as the U.S., although with some comparative references to developing countries. We 
distinguish among asset management, marketing and record-keeping costs, showing how each varies with type of system.

Empirical evidence presented in this paper and elsewhere suggests the existence of large economies of scale and scope in asset management. All three option exploit these economies, but in different ways. The retail market (option 1) allows individual investors to benefit from scale economies in asset management, but at the cost of high marketing expenses-almost half of total costs--that are needed to attract and aggregate small sums of money into large pools. In contrast, a centralized fund (option 3) can be much cheaper because it achieves scale economies without high marketing costs, but gives workers no choice and hence is subject to political manipulation and misallocation of capital.

The system of constrained choice described in this paper (option 2) is much cheaper than the retail market and only slightly more expensive than a single centralized fund. It obtains scale economies in asset management and record-keeping while keeping marketing costs low and allowing significant worker choice that helps to insulate it from political interference. Most of the cost savings under constrained choice are attributable to efficiency gains, although a smaller part stems from increased bargaining power that redistributes fixed costs away from the mandatory system.

Part I puts this paper into international perspective, by summarizing the choices between the three alternatives that have been made in different countries and by examining costs in the mandatory AFP system in Chile, which uses the most common method, the retail market (option 1).

Part II draws on data from voluntary saving in mutual funds in the U.S. Both in Chile and the U.S., individuals have diversified accounts that they can move from one company to another in a competitive retail investment market. The American mutual fund industry is vastly more developed and competitive than the Chilean AFP industry. Nevertheless, we find strong similarities between Chilean AFP's and American mutual funds, in terms of annualized costs as a percentage of assets and the composition of these costs. Average annualized costs range between $1 \%$ and $1.5 \%$ of assets for most investors, and marketing is the largest cost component in both cases. In Chile annual costs are less than $1 \%$ for those who start contributing early in their careers. In the U.S. a low-cost niche of less than $1 \%$ has developed for passively managed funds indexed to various benchmarks. In both cases costs were higher 15 years ago and have 
declined as a result of asset growth and competition. These two cases are predictive of how an IA system is likely to develop in the retail market.

Part III explores the cost of asset management in the institutional market, drawing on U.S. data once again. Institutional investment costs-consisting of money management, internal administration and brokerage fees for pension funds and other large organizations--are estimated to be $4-8$ basis points (.04-.08\% of assets) for passively managed portfolios, and 35-65 basis points (.35-.65\% of assets) for actively managed domestic portfolios, depending on type of asset-much less than the mutual fund retail market. These large cost savings are due to economies of scale in the investment function, much smaller costs in the marketing functions, the virtual absence of record-keeping costs, and the greater bargaining power of large investors in an industry where average costs greatly exceed marginal cost. These would also be the costs in a well-run centralized funded pillar with no IA's and no choice (option 3).

Part IV considers whether and how an IA system with constrained choice (option 2) could be set up to benefit from these same economies regarding asset management. We outline the elements of such a system-which include worker choice among a limited number of money managers chosen through a competitive bidding process or through a fee structure that discourages marketing expenditures, especially sales commissions. We estimate that such a system could operate with approximately the same asset management costs as the centrralized fund, but with slightly higher advertising expenditures.

However, additional record-keeping and communications costs will necessarily be incurred if workers have individual accounts with differing asset managers. Part $\mathrm{V}$ therefore investigates the cost of these record-keeping expenses, using data from the transfer agent function of mutual funds and the experience of the federal employees Thrift Saving Plan. We find that costs per account depend on level of service provided, especially the level of personalized communications. As part of their competitive marketing strategy, most mutual funds have provided a high service level, in which users of multiple transactions and expensive communications are not penalized and, in fact, are subsidized by non-users. A more modest level of service and efficient charging method, with incremental personalized service available at a fee, would cost less than $\$ 20$ per account.

Thus, the long run steady state cost in a constrained IA system in countries with well developed financial markets is likely to be .14-.18\% of assets annually for a passively managed 
investment strategy, including all money management, brokerage and record-keeping fees (and $.49-.79 \%$ if active management options are chosen). This is only slightly higher than the cost of a centralized scheme (.04-.65\%). It is much less than the expected return to saving or the cost of voluntary or mandatory individual accounts in retail markets (.32\%-1.5\%). Constrained choice offers large administrative cost savings combined with political insulation, that imply a Pareto improvement so long as choice is not constrained "too much."

\section{How High Are Administrative Fees in Chile and How Are They Spent?}

Countries with mandatory defined contribution (DC) systems have made differentiated policy selections among the three structural alternatives listed above, but most of these are too new to enable us to estimate their long run costs. Interestingly, they all constrain investment choice in some way, albeit with different objectives. Chile and most other Latin American countries use alternative 1 , the retail market, to manage the funds in their mandatory DC pillars. Pension companies (AFP's) can freely enter the market, subject to licensing requirements, and workers are free to sign up as individuals with the company of their choice. The AFP's must abide by detailed regulations controlling their investment portfolios, designed to avoid disastrous investment outcomes, rather than to minimize costs. Marketing costs are high and economies of scale not fully exploited, but mergers are slowly solving that problem.

Sweden, which has just adopted a multi-pillar system, uses alternative 2: All mutual funds in the country are free to participate providing they negotiate a fee agreement with the public agency that administers the system and maintains all records. Workers can select the funds of their choice, but contributions are aggregated and moved by the agency in large blocks, similar to omnibus accounts. Funds will not have information identifying their members-a feature designed to discourage sales commissions (although not mass advertising). The goal is to utilize economies of scale and scope and bulk bargaining power to reduce costs, while still allowing considerable choice. Since the system has not yet been implemented, we do not know how well it will succeed.

Bolivia recently used a much more wholesale approach: it auctioned off the money management rights in its DC pillar to two investment companies, in an international bidding process that took both past performance and future fees into account. Choice is very constrained 
(although expected to increase in the future), and costs are lower than in Chile (although marketing costs are incurred in a deliberate effort to increase coverage).

Singapore and Malaysia did not even offer this much choice until recently. They required workers to put their DC contributions into publicly-managed central provident funds which invest the money. The government unilaterally sets the rate of return it will pay on workers' accounts (alternative 3). Administrative costs are small and marketing costs absent, but returns to workers' accounts and therefore eventual pensions are also low. Partly for this reason, Singapore recently allowed workers to opt out of the central fund and invest their balances above a specified level in privately managed accounts. About 25 international asset managers were authorized to handle these accounts. Collections and over-all administration remain centralized. To summarize: a continuum in funded DC pillars currently exists, ranging from high choice in the retail market (e.g. Chile) to more constrained choice through the institutional market (e.g. Sweden, Bolivia) to practically no choice at all (Singapore and Malaysia until recently). ${ }^{2}$

In this section we examine the annualized administrative costs of Chilean AFP's, which have been operating since 1981. These costs have been subject to great criticism by opponents of IA systems. In Chile the worker pays a fee to the AFP, which is an administrator that sets up the fund and runs it. All assets in the fund are owned by its worker-participants. All expenses are paid by the AFP, not the worker or the fund directly. So fees do not necessarily represent real costs of operating the fund, especially in the short run. AFP's made losses in the early years of the new system when they incurred start-up costs that exceeded their revenues. The industry as a whole is quite profitable at this stage, due to price insensitivity among investors and entry barriers in the form of high marketing costs needed to attract customers. System maturation, evolving regulations and mergers seem to be changing the structure of competition, making the average AFP larger and the industry more oligopolistic. ${ }^{3}$ These developments may alter costs and their relationship to fees in the future. The current fees, however, are costs to investors that reduce their net returns, so we examine them in this section.

Chile adopted an unusual method of charging fees: the fee is imposed when the contribution first enters the system, and no management fees are charged on that contribution thereafter. The fee started at over $20 \%$ of contributions but has fallen to an average level of 15\%. (In other Latin American countries, such as Argentina, where the contribution rate is smaller but expenses very similar, fees are still $20 \%$ of contributions or even higher). That entry 
fee covers a lifetime of investment management by the initial AFP or any AFP to which the funds are moved later on. This extremely front-loaded method was adopted as a way to cover start-up costs at a point when the system had no prior assets, only new contributions. In effect, workers "lent" some of the start-up costs to the AFP's in return for free lifetime money management for the rest of the accumulation phase.

However, it is necessary to convert these front-loaded fees into their annual equivalents (that will yield the same final year accumulation), in order to calculate their impact on net returns over workers' lifetimes and to make them comparable to mutual fund or pension fees in the U.S. or elsewhere. This requires a simulation of how long the worker will keep his or her money in the system, which in turn depends on the age and career pattern of the worker.

We have simulated the average annual fee on assets that is equivalent to the front-loaded $15 \%$ fee on contributions, for workers of different ages at the point when the contribution was made (Table 1). For a 25 year old worker (whose money will stay in the system for another 40 years), the $15 \%$ one-time fee is equivalent to $.43 \%$ of assets annually; for a 45 year old worker it is $.87 \%$, and for a worker who contributes monthly in his final year it is $32.1 \%$ (column 1). For a worker who contributes every year for 40 years (e.g. age 25-65), paying a fee on each new contribution, the annual equivalent of all these front-loaded fees is .73\% (column 3 ). These calculations assume a 5\% gross rate of return. We have done the same calculation with $3 \%$ and $4 \%$ rates of return and the results are very similar.

Many workers will contribute for 20 years only, because this is the period that makes them eligible for the minimum pension guarantee. For these workers, the equivalent annual fee depends on whether the contributions were made early or late in their careers, which determines how many years their money will be under management. If a worker contributes only for his first 20 years of employment the equivalent average annual fee for all his contributions is .55\%, while if contributions are made only in the last 20 years, the equivalent average annual fee is $1.59 \%$ (column 2).

The average annual equivalent is therefore much lower for young than for older workers. Workers with different employment histories will end up paying different costs as a subtraction from their gross returns - probably not desirable features of mandatory systems. Front-loading of fees may induce evasion among workers in their later years. The possible reluctance of AFP's to 
accept transfers of funds from older workers, who will make only small contributions relative to their assets, also represents a drawback.

We cannot calculate a true average over all workers without knowing the distribution of contribution histories that will evolve over the next half century. But 20 years of contributions are a likely focal point since that entitles workers to the minimum pension guarantee. Suppose that one third of all workers contribute for 40 years, and one third each for their first and last twenty years. The system-wide annual equivalent expense ratio would be $.96 \%{ }^{4}$

These estimated lifetime fees are very similar to average mutual fund fees in the U.S. (Part II). American mutual funds, of course, provide much greater diversification and service than Chilean AFP's, which would make their costs higher. But they also benefit from much greater economies of scale, which would make their costs lower. AFP costs are much lower than costs of U.S. mutual funds that operate in emerging markets. They are much lower than mutual fund fees for voluntary saving in Chile, which average around 6\% per year for equity funds and $2 \%$ for bond funds. These mutual funds also have minimum balance requirements that make them inaccessible to the average Chilean worker. AFP fees are also lower than those of mutual funds in Europe, where the combination of front loads and annual fees exceeds levels in the U.S. Chilean AFP's are therefore relatively inexpensive if the standard of comparison is fees in other financial institutions that invest individuals' savings in competitive retail markets.

The breakdown of costs among AFP's shows that over $45 \%$ of total expenditures were used for marketing costs, especially sales commissions (Table 2). This number (which omits staff salaries involved in marketing), is similar to marketing expenses in the retail financial markets in the U.S. and other countries. These similarities suggest that a study of U.S. mutual fund data will yield insights into how costs might evolve in individual account systems and how these costs might be reduced.

\section{Costs in the Retail Market of American Mutual Funds}

The mutual fund in the U.S. has been a hugely successful financial institution. Assets have grown from less than one billion dollars in 1949 to almost $\$ 140$ billion in 1980 to over $\$ 4$ trillion by the end of 1997 and now exceed the combined total of savings bank deposits and life insurance assets. The variety of fund objectives and ancillary services has also escalated, with 
equity funds expanding much faster than bond or money market funds over the last 20 years. Savers apparently feel that investing through mutual funds gives them advantages in terms of convenience, liquidity and diversification which justify the fees.

Our object was to analyze the determinants of these fees and how they are spent, in order to shed light on how costs might evolve or might be shaped in a reformed social security system that includes individual accounts. Fees are not exactly equivalent to real social costs because funds may run short and medium term profits or losses and for several other reasons listed below. Nevertheless, fees indicate private costs that reduce net returns to shareholders and in the long run they should approximate real costs. In this paper, for simplicity, the two terms are used interchangeably, while recognizing all the reasons why this is not precisely the case.

We used regression analysis and frontier analysis based on a large data set of mutual funds (4254 funds in 1997 and 1300-2000 each year for 1992-96) that we obtained from Morningstar. We also culled information from annual reports, fund prospectuses, and financial statements filed by their investment advisers, as well as surveys conducted by the association of mutual funds and discussions with fund officials and their transfer agents. Money market funds, which comprise about a quarter of the fund universe, were largely excluded from this study, because they involve short term deposits, high transactions levels and related costs that would not be applicable to IA's in social security systems. Mutual funds with missing data for important variables were also excluded. We included only "open-end funds" whose shares are bought and sold at net asset value-total assets divided by total shares. Table 3 summarizes the resulting fund universe for two representative years, 1992 and 1997.

In the U.S., like Chile, mutual funds are organized by sponsors, but they are not owned by these sponsors. Instead, the assets are owned by the shareholders who invest in them. A board of directors (most of whom are affiliated with the sponsor) chooses the investment adviser who, in almost all cases, is the original sponsor of the fund. Often the same sponsor starts multiple funds in a fund complex such as Fidelity or Vanguard. The adviser makes key strategic decisions, hires analysts and portfolio managers (who handle day-to-day investment activities) and provides other administrative service to the fund. The fund itself has few employees and functions. Competition takes the form of investors exiting and entering funds rather than funds choosing and re-evaluating investment advisers (see Baumol et al, 1989). Marketing, service and 
product differentiation have been major instruments in the competition among funds for investors.

Unlike the situation in Chile, most fees are paid by the fund (not directly by the shareholders)--to the investment adviser, to distributors of the fund (in the case of the so-called $12 \mathrm{~b} 1$ fees) and, in much smaller amounts, to lawyers, auditors, transfer agents and others (Table 4). These fees, as a proportion of assets, determine the fund's reported "expense ratio" that it subtracts from its gross return to obtain the net return passed on to shareholders. Front-loaded and back-loaded sales commissions that go directly from investors to brokers or other distributors are not included in this expense ratio but nevertheless represent a cost to relevant shareholders. Brokerage fees paid for securities transactions are also excluded from the expense ratio and are simply netted out of the fund's reported gross returns.

We have constructed a "total fund expense profile" which equals the reported expense ratio plus average brokerage costs plus annualized front loaded sales commissions (Table 4$).{ }^{5}$ In 1997 the total fund expense profile was $1.85 \%$ of assets, compared to the reported expense ratio of $1.28 \%$. Weighted by assets, these numbers fall to $1.43 \%$ and $.91 \%$, respectively. Assetweighted numbers are more relevant for our purposes because they indicate the expense incurred by the average dollar invested. The lower asset-weighted figures are consistent with economies of scale and/or a selection of clients into low cost funds. The variation in costs is also great. For example, the average dollar invested in passively managed funds incurs an expense profile that is only one-fifth the expense of a dollar invested in actively managed funds.

More than half of the reported expense ratio (one-third of the total expense profile) is paid to the investment adviser, who then allocates the money among the factors of production. To understand the production function of the mutual fund it would be helpful to know how this money is spent-how much on investment research, advertising, development of new products and technologies, etc. This information is difficult to obtain since most fund sponsors are private companies which are not required to disclose their records.

Other problems related to measuring and understanding mutual fund costs are:

1. Disclosure of brokerage costs (for securities transactions) was not required until 1996 and they are reported for only a subset of our funds for 1996 and 1997. 
2. Some brokerage fees cover research or other expenses of the fund or its adviser (i.e. the "soft dollar" issue), thereby reducing the reported cost that goes into the expense ratio and understating real expenditures on these items.

3. Some investment returns are reported net of cost, without data for the cost of producing them.

4. Income from securities lending operations is sometimes used to offset custodial and other expenses, which are therefore underestimated by reported fees.

5. Some funds do not report number of shareholders and the growing use of omnibus accounts that consolidate many shareholders further complicates the use of this explanatory variable.

6. Investment advisers temporarily waive some fees, especially fees of new funds, as a business strategy to attract new customers, but may later reinstate them; these temporary fees may not reflect real costs.

7. The data set includes only funds that were still operating in 1997 and it therefore suffers from survivorship bias. Many expensive or poorly performing older funds have terminated, which may lead to an understatement of costs or an overstatement of expected returns.

8. Many shareholders pay a front loaded one-time sales charges directly to brokers or other sales agents. These charges are not reported as fund expenses. To include them we had to annualize them based on estimated holding periods on which we lack good data, so caution is needed to interpret these estimates of marketing expenses.

9. The invisible diseconomy of scale - the impact of a fund's buying and selling activities on security price-is not measured here. This may lead to an overstatement of scale economies, especially in thin markets where the fund owns a large part of total capitalization.

10. Most funds are members of a mutual fund complex (e.g. Fidelity and Vanguard). Certain activities, such as advertising and new product development, are jointly supplied to all members of the complex by the common investment adviser. The allocation of these expenses among the funds may be influenced by estimates of where the expenses can be absorbed with least loss of clients (see point \#6 above). Thus, the relative fees paid by members of a fund complex do not necessarily reflect 
the real cost of producing them. Moreover, business strategy concerning joint cost allocation may be different in a mandatory system.

However, except for the last point, we do not believe that these problems affect our major results.

Specification of regressions. The main dependent variable in our regressions is the "expense ratio"- - reported expenses (excluding brokerage fees and loads) as a percentage of assets. We did not use the "total fund expense profile" as our dependent variable because reliable data were not available for holding periods by fund or on brokerage costs for most funds in the data set. Brokerage fees for securities trades were also examined in a separate regression using the smaller subset of funds for which they are available. Front-loaded sales commissions are not part of the expense ratio but they appear as an independent variable and are discussed as a marketing cost.

We sought to determine the extent to which cost variation is random or systematic and to identify the determining factors for systematic variation. Our strategy was to view asset investment and shareholder servicing as the main outputs, hence magnitude of assets and number of shareholders as the core determinants of costs, controlling for a large number of other variables. This was also the strategy followed by Baumol et al (1989), but we include many additional control variables designed to throw light on how an IA system might operate and might be shaped by business strategy and public policy. Our independent variables fall into three main groups - a core group capturing economies of scale and scope as well as the relationship between costs, returns and risk; an asset allocation group acknowledging that different real costs are implied by different portfolios; and a business and marketing strategy group reflecting decisions made by the fund's adviser (Table 5).

\section{Core group:}

Assets (in billion dollars)

Asset $^{2}$

Assets in entire fund complex

Number of accounts (in thousands) or, alternatively, average assets per account

3-year gross return or, alternatively, 3-year load-adjusted net return

3-year standard deviation of returns

\section{Asset allocation group}


Dummy variables for funds that specialize in bonds, small cap stocks, special sector stocks, international (industrialized country) funds, emerging market funds, with large cap stock funds as the omitted category.

\section{Business and marketing strategy group}

Minimum investment required

Stock turnover rate

Fund age

Dummy variables for funds that sell only to institutional (very large) clients, index funds, bank-advised funds, funds with low (.25\% or less) and high (between .25\% and 1\%) $12 \mathrm{~b} 1$ fees, funds with front loads and deferred loads.

We ran the OLS regressions for 1997. We also conducted a frontier (envelope) analysis for 1992-97, which included a time trend as an additional variable. Tables 6 and 7 report results from several OLS and MLE specifications, which yield a consistent picture of the determinants of mutual fund costs. The OLS regressions explain $64 \%$ of the variance when all the above variables are included. The "business and marketing strategy" group accounts for more than half of the predictive power. Most of the variance in costs is therefore systematic rather than random. Costs faced by investors vary in large part because of business choices made by fund managers and these same costs could be substantially influenced by policy choices in a mandatory IA system.

Economies of scale and scope. As expected, we found considerable evidence of economies of scale and scope. These show up in two ways in our regressions. First, expense ratios fall when total assets in fund and assets in the entire fund complex increase. For funds with assets of less than $\$ 10$ million the simple average expense ratio is $1.54 \%$, while for funds with assets of more than $\$ 1$ billion it is $.96 \%$. Second, expense ratios fall when assets per shareholder and minimum size of investment increase. We discuss each of these in turn, since they have different explanations and implications for the operation of IA systems.

The basic reason for the first effect is that all funds need industry analysts, portfolio managers, computers and access to electronic trading facilities. Large funds, however, can be managed with virtually the same staff and trading access as smaller funds. Much of the scale economies may come from marketing costs rather than from investment management: large funds spread their advertising expenses (and less importantly, their legal, accounting and audit 
expenses) over a larger asset base. Partly for these reasons, the largest and fastest growing mutual funds also experienced the greatest drop in operating expenses over the last 20 years (Rea and Reid 1998. For more on sources of scale economies see Baumol et al 1990, Sirri and Tufano 1993).

On the one hand, scale economies may be somewhat underestimated in these regressions because fund complexes may subsidize their new smaller funds, charging them less than full costs while they are "infants", and earning a higher profit margin on their large well established funds where clients may be less responsive to small differences in fees. On the other hand, scale economies may be overstated for certain types of assets such as small cap and emerging market stocks. These regressions did not analyze the interaction between asset class and scale. Reverse causation may also be at work: low-cost funds may have attracted large amounts of assets rather than vice versa. We were not able to distinguish between these two effects in this paper.

These economies from asset aggregation do not continue indefinitely. The positive sign on the coefficient of $\mathrm{Asset}^{2}$ in the regressions brings to a halt the fall in expense ratio when fund size reaches the $\$ 20-\$ 40$ billion range. Other studies have found that scale economies stemming from the size of entire fund complex may stop at \$20-40 billion in the U.S. and at 2.9 billion francs, a much lower level, in France (Collins and Mack 1997; Dermine and Roller 1992) Price impact, not measured here, also places brakes on scale economies, especially in illiquid markets. The fact that many small funds co-exist with larger ones is further evidence of the limits to scale economies and also of the gradualness of the market process in adjusting to these economies. Most mutual funds are not yet operating at the least-cost scale, suggesting that mergers may take place in the future, in the U.S. as in Chile.

On the second effect: the expense ratio falls if minimum investment or average assets per shareholder grow. Along similar lines, holding aggregate assets constant, the expense ratio increases with number of shareholders, but this effect disappears once strategy variables such as minimum investment are controlled. The basic reason here is that funds incur a fixed cost per account for record-keeping and shareholder service (the transfer agent function), so the larger each account the smaller this cost will be, as a percentage of assets.

Two important implications for IA systems grow out of these sources of scale economies. First, aggregation brings economies. The limit to these economies nevertheless leaves space for numerous mutual funds, in the U.S. and in many other countries. IA accounts could be one part 
of this huge financial system, employing the same investment managers and enjoying the resulting economies of scale and scope. But even if IA funds and their managers were completely segregated and even with a small contribution rate of $2 \%$, a mandatory IA system in the U.S. would generate over $\$ 60$ billion of new contributions annually. Such flows are large enough to offer options among many fund managers at a cost-effective scale.

Second, the fixed record-keeping and communications cost per account poses a potential problem for IA systems if the accounts are small. Currently, most mutual funds have a minimum investment of $\$ 1000$ or more and the average account size exceeds $\$ 25,000$. This produces a weighted average transfer agent expense ratio of .12\%. This expense ratio would be much higher than $.12 \%$ and in fact would exceed $1 \%$, simply for the fixed cost per account of recordkeeping and communication, if mutual funds were used to serve numerous small IA accounts (see Section V for more details). This suggests that some other method must be found to deal with the transfer agent function if the object is to keep costs low, particularly in the early years of an IA system.

Marketing costs. Maximizing assets under their control is, in most cases, a key objective of investment advisers, since their income depends on it. Aggressive marketing strategies have been developed with this object in mind. Using brokers, other sales persons and mass advertising methods (media adds, direct mailings), the industry has successfully called to the attention of potential shareholders the advantages of equity investing, using mutual funds as the vehicle. This probably accounts for a large part of the industry's dramatic growth in assets. Other studies have shown that the funds which have gained the most are those that combine vigorous marketing with good performance (Sirri and Tufano 1997). The possibility of spreading favorable information by marketing probably acts as a spur to good performance and product innovation. At the same time, marketing itself leads to substantially higher costs, that are unevenly distributed among investors.

The major marketing expense to shareholders consists of sales commissions. Over two thirds of all funds are sold through third parties (brokers, insurance agents, financial planners) who receive some kind of commissions (through front or deferred loads or annual $12 \mathrm{~b} 1$ fees). However, the proportion of assets managed through direct marketing is larger than the proportion of funds and has been increasing through time. (Tables 3 and 8). 
How much do marketing fees add to total expenses? It is possible that sales commissions may substitute for other costs, such as advertising or transfer agent fees (see discussion of transfer agents in Part V)? Our regressions, however, show little trade-off. Most of the 12b1 fee is passed on to consumers as an additional cost. A low $12 \mathrm{~b} 1$ fee (usually .25\%), which is included in the expense ratio, raises the expense ratio $.2 \%$, a high $12 \mathrm{~b} 1$ fee (usually $1 \%$ ) raises it $.4 \%$ and the latter is usually found together with a deferred load which raises it another $.5 \%$, implying that most of the $12 \mathrm{~b} 1$ fee is an added cost. A front load (a one-time fee of 4-5\%, not part of the expense ratio) increased the expense ratio in some regressions but not others. The coefficients on front and back loads may be due to the multicollinearity between loads and other cost-raising variables such as $12 \mathrm{~b} 1$ fees, high turnover and expensive active management, rather than to their direct effects. (See discussion of institutional funds and index funds below. For corroboration of the cost-raising effects of $12 \mathrm{~b} 1$ fees see Ferris and Chance 1987, Trzcinka and Zweig 1990)

The "total annual marketing cost" paid by the shareholder may be defined as the 12b1 fee + annualized front load, and the "total fund expense profile" as the expense ratio + brokerage costs + annualized front load. (Back loads are omitted because, given holding periods under self-selection, they are negligible for most investors). Then, marketing costs are $35 \%$ of all fund expenses on a simple average basis or $43 \% \%$ on an asset-weighted basis, most of these costs are for sales commissions, and the total expenses of funds charging these fees increase commensurably as a result (see endnote 5 and Table 8). For funds with front-loads, our estimated total expense profile is almost 1 percentage point higher than for funds that pay no sales commission. Marketing costs played an even more important role in the early years of the mutual fund industry, before no-loads developed. The marketing share of total expenses in the U.S. mutual fund industry is very similar to that of AFP's in Chile.

The 35\%-43\% average undoubtedly understates true marketing costs. It does not include the salaries of staff who manage the marketing efforts or advertising costs that are paid for out of the adviser's fee. To fill in this gap, we examined the annual reports of five investment adviser companies that are publicly traded (hence required to disclose additional information). Advertising expenses in 1997 were 14\% of total adviser expenses for one such company that deals in no-loads. Marketing costs (including sales commissions and advertising) averaged 50\% of total costs among the four public investment management companies that deal through 
brokers and other intermediaries. ${ }^{6}$ An average investor with 5 mutual fund accounts of $\$ 20,000$ each pays $\$ 1000$ per year for the information he gets from marketing, if total costs of these funds, including loads, are $2 \%$ of assets and marketing costs are $50 \%$ of the total.

Investors have the option, of course, of purchasing no-loads. This implies that, rightly or wrongly, they believe they receive value from the third party intermediaries with whom they deal. (For corroboration see Kihn 1996, Capon et al 1996). From a social point of view, marketing probably provides a mixture of useful information, misleading information, an impetus to good performance and zero-sum game raiding. The mix of these elements is important. Most methods to keep IA costs low involve a reduction in marketing expenses, under the assumption that it is not the most efficient way to provide useful information to new investors. This is discussed further in Part IV.

Institutional funds. A small number of mutual funds or special classes within a large mutual fund are limited to institutional investors (i.e. bank trust departments, corporations, small foundations, etc.). Usually the minimum investment for these funds is $\$ 100,000$ or higher. The dummy variable for these funds has a significantly negative coefficient $(-.15 \%)$ as compared with funds for individual investors-due to their lower record-keeping and advertising costs. Expense ratios for institutional funds are even lower, when their lower sales commissions (which are controlled in these regressions), are taken into account. The same assets can be amassed with much lower distribution and record-keeping expenses from large institutions than from small individuals. Institutions are much less likely to pay $12 \mathrm{~b} 1$ (or front loaded fees) to brokers because they have more efficient ways of getting information. On the rare occasions when they pay these fees, they obtain lower rates. As a result, the institutional coefficient jumps to $-.53 \%$ when sales commissions are left out of the regressions. The total expense profile of institutional funds, including loads and brokerage fees, controlling only for asset allocation, is less than half those of retail funds. (Table 9, Panel C).

Passive v. active management. Also important is the significant negative sign (-.39 to $.52 \%$ ) on passively managed funds, also known as index funds, which do not have to pay the high fees that popular active managers command. Passively managed funds mimic or replicate a stated benchmark, such as the S\&P 500 or the Russell 2000. The manager does not engage in discretionary stock selection or market timing and therefore cannot claim a fee for superior information or judgement. Index funds generally benefit from low turnover, which reduces the 
expense ratio as well as brokerage fees. They are less likely to engage in heavy marketing; the coefficient becomes - .52 when sales commissions are omitted from the regressions. Controlling only for asset allocation, fees of passive funds are less than one-third those of actively managed funds in the retail market (Table 9, panels B and C). In effect, passive investors free ride on the information provided by the actions of active investors. Passive investment strategies would have the additional advantage in a mandatory system of reducing the variance in returns among participants.

The large negative sign on index funds should be interpreted with some caution, however. It could mean that fund complexes view these funds as the products that are designed to capture price-sensitive consumers, and for this reason they may allocate their joint expenses (advertising, new product development) to the other members of their complex. (For example, Fidelity is currently waiving part of its normal management fee on its S\&P 500 index funds, in order to make them more competitive.) Further along these lines, record-keeping and other charges tend to be less for passively than for actively managed funds; this may be a business strategy decision rather than a reflection of real cost differentials. The real cost savings to the economy from index funds may therefore be overstated by our coefficient, although they remain real cost savings to individual investors.

Asset allocation: international funds. Asset allocation has a major impact on costs. The dummy variables for asset classes have large significant effects--although the total $\mathrm{R}^{2}$ does not change much in comparison with the core group. Bond funds have lower costs and small cap or specialty funds have higher costs.

Expenses are highest in international funds, especially emerging market funds-as a result of the greater difficulty in obtaining information in these countries, their less developed markets which result in high bid-ask spreads, high transactions and custodial costs, currency hedging costs and the absence of passive investment opportunities in contexts where the relevant companies and their prices fluctuate widely. These factors would also apply to local funds operating in emerging markets, although institutions based in a country needn't hedge against currency risk and may have an informational advantage over those that are based in a foreign country. Chilean AFP costs appear surprisingly low in this context.

Descriptive statistics concerning the average expense ratios for funds in different asset classes are presented in Tables 3 and 9. We see there that asset allocation matters, but regardless 
of assets chosen, passive investment cuts costs drastically, as does investing through the institutional market.

Brokerage fees. Brokerage fees paid for securities transactions average $.26 \%$ of assets for the subset of funds in our sample that included these data. Weighted by assets, average annual brokerage fees fall to .12\%. Recall that these fees are not included in the expense ratio but they are deducted from gross returns. Separate regressions on this subset show that brokerage fees exhibit economies of scale with respect to assets, especially assets in fund complexes, as large fund families use internal trading and spread the fixed costs of electronic trading over a larger base. Brokerage costs are higher for international funds, especially in emerging markets, and they are, of course, strongly dependent on securities turnover rates (Table $10)$.

The typical brokerage fees paid by mutual funds apparently exceed "best execution fees" charged by deep discount brokers or commissions paid by large institutional investors by a factor of 3 or 4 (Livingston and O'Neal 1996; and Table 12). One possible reason is that brokerage fees are not included in the expense ratio, which is the most widely reported expense figure. They were not even disclosed until 1996. Reported expenses could be reduced by covering some research and marketing services out of transactions fees paid to brokers - the controversial "soft dollar" issue. It will be interesting to see if disclosure and, in fact, a glaring spotlight, will change fund behavior in this respect.

Net returns, gross returns and risk. Of course, the investor ultimately cares about net returns, not the expense incurred in earning them. If higher costs led to higher returns, they would be worth incurring. However, this does not seem to be the case. In fact, some of the same factors that increase costs actually reduce returns (Table 11).

Most important, larger assets under management increase both gross and net returns, while decreasing costs. Funds with front loaded fees don't earn higher gross returns, so their load-adjusted net returns are lower than for no-loads. Index funds earn significantly more than actively managed funds, both net and gross, but other evidence indicates that this effect varies by asset class. The advantage of index funds is greatest for large cap funds operating in very liquid markets and is much less for small caps and international funds, especially emerging markets, where markets are less efficient and private information plays a more important role (Muralidhar 
and Weary 1998). Institutional funds have marginally higher net returns and funds with high turnover have marginally lower net returns.

These results from separate equations are consistent with the negative sign on gross and net returns as a control variable in our expense ratio equations. Cost and returns, especially net returns, appear to be negatively correlated. Thus, strategies involving high administrative costs do not seem to be justified on grounds that they raise returns. (For further evidence on the zero or negative relationship between costs and returns see Cahart 1997, Elton et al 1993, Malkiel 1995, Malhotra and McLeod 1997, Washington Post, Sept. 13, 1998, B1).

Changes over time. The question of whether expense ratios have been going up or down over time has been hotly debated (see Lipper 1994). This is an important question because it tells us whether policy makers can rely on market forces to reduce costs. For the period in this study, time has a small significant positive effect on the expense ratio (1-2 basis points per year), after controlling for all our other variables. Total expenses (expense ratio times assets) have gone up much more as a result of asset growth. But funds that have operated for the entire period have lower expense ratios than others (the negative coefficient on Fund age). This may be partly due to "learning by doing" and partly due to a selection process: they have survived because they are low cost funds.

These estimates do not take into account changes in marketing costs and consumer responses to them. Between 1992 and 1997 a shift of investors toward no-loads and a decrease in the size of front loads led to a small fall in the total fund expense profile, despite the rise in the reported expense ratio (Table 8). Over a longer time period (1980-97), it appears that costs to the average investor have fallen more substantially, for the same reasons. Non-marketing expenses have risen over the same period (Rea and Reid 1998). More recently, investors have been shifting into cheaper passively managed funds.

However, the movement to lower cost and higher performing funds generally occurs through the flow of new money to the funds rather than the reallocation of old money. The process, therefore, has been very gradual and some poorly informed investors have not participated in it (Ippolito 1992, Patel, Zeckhauser and Hendricks 1994, Sirri and Tufano 1997, Gruber 1996). The slowness may be due, in part, to the generally robust stock market since 1980. Costs have been small relative to returns and the vast majority of investors in diversified mutual funds have fared well, even those in high cost funds. Costs are likely to become more 
important as a determinant of net returns and peoples' investment decisions, when gross returns decline.

This evolution of the mutual fund industry is suggestive of how a mandatory IA system might evolve in the retail market. Assets will increasingly be concentrated in large investment companies which exploit scale economies. New niche firms and products will spring up, resulting in wide consumer choice (regulations permitting). A heavy emphasis on marketing activities and expenses will provide a mixture of useful and misleading information to clients. Finally, we would expect a gradual movement toward high performing, low cost funds but with considerable variance. Recently, performance-based fees have been adopted by some of the largest funds, which may prove to be an indirect way of decreasing fees of managers who underperform their benchmarks. The movement toward low cost funds would probably accelerate with a mandatory IA system. However, the difficulty small investors may have in processing cost and return information, together with the greater profitability of large investors to funds, would retard this process. Although lower cost funds will be available, we would expect many investors to pay more than $1 \%$ of assets annually, over long periods.

\section{Institutional Investments: The Cost of Bulk Asset Management Alone}

The importance of the institutional dummy led us to investigate further the degree to which costs are lower for managing large asset balances. Mutual funds are limited in their ability to charge lower fees for large investors. Regulations require funds to charge all investors the same expense ratio, unless they create separate classes of shares that incur different expenses. Thus, institutional investor classes are usually not charged for shareholder services or distribution, because it can be demonstrated that they do not incur these costs, but they are charged for a pro rata share of the investment adviser and other fees. This treatment makes it possible for mutual funds to compete for small institutional accounts (e.g. of \$1-20 million, owned by bank trust departments or corporations). However, it puts them at a disadvantage when competing for larger accounts. Larger institutions (e.g. DB plans of major corporations and public employers) can get better money management rates elsewhere.

Table 12 presents illustrative sliding scale cost data on investments up to $\$ 200$ million provided by a large manager of institutional funds operating outside the mutual fund framework. 
It also shows median costs for 167 large and 10 of the largest U.S. pension funds (median large fund $=\$ 1.5$ billion, median assets per money manager $=\$ 113$ million; median largest fund $=\$ 42$ billion, median assets per money manager $=\$ 543$ million). These can be considered pure money management costs because marketing and record-keeping costs are virtually absent.

Table 12 shows clear evidence of scale economies, the cost efficiency of passive management, and the impact of asset allocation. Fees as a percentage of assets decline over large ranges with volume of assets managed. Marginal fees are as low as 1 basis point for passive management of large cap stocks and 2.5 basis points for small and mid-caps, once assets in an account reach $\$ 200$ million. Passive fees cannot go much lower, and indeed are not lower even for the largest pension funds. So there appears to be no strong cost reason for aggregating passively invested amounts beyond a half billion dollars.

Fees for active management are higher, but still far less than the $1 \%$ fee they would pay in the mutual fund market. For assets exceeding \$25 million, investors must pay 35-50 basis points. Median fees for active management in the largest pension funds are only 25 basis points, suggesting that cost cuts continue past the $\$ 25$ million point. The fact that even the largest pension funds use multiple money managers (an average of 34), and allocate less than a billion dollars on average to each active manager, is evidence that, to them, diversification benefits eventually outweigh scale economies. (Recall that mutual funds realize scale economies until a much higher point, $\$ 20-\$ 40$ billion, but some of their economies come from advertising and other non-investment functions).

Money management rates for emerging market investments are much higher than for domestic investments, but advantages to large institutional investors remain. For active management they pay a marginal fee of $.8 \%$ and for index funds only .4\%. These numbers again suggest that asset management is much more expensive in developing countries, because transactions costs are higher, markets are less efficient and passive investment opportunities are unlikely to be available. Moreover, investment companies in the third world have less money at their disposal, so they are less able to benefit from scale economies. The large institutional investor in the third world nevertheless fares much better than the small retail investor, which has implications for how these countries might set up their IA systems.

Why do institutional investors get such a good rate? The answer lies in better information, greater bargaining power and lower costs. In an imperfectly competitive market, 
large investors have greater reason and resources to seek out money managers who will charge them a fee close to marginal cost. They also have the credible threat of managing their money in-house if they do not get good terms from an external manager. The more they have to invest, the greater their marginal profitability to the money manager and the greater their bargaining power. This is an arena where each agreement is slightly different and personally negotiated. Even a small fee above marginal cost per unit invested adds up to a large contribution toward the asset manager's fixed costs, in the case of a large institutional investor. Thus, even if a million small investors with $\$ 1000$ each, cost the same total amount as one institutional investor with $\$ 1$ billion, the latter would probably end up with a smaller fee as a percentage of assets as a result of better information and bargaining power.

Costs, however, are not the same because record-keeping, shareholder service and marketing costs are much less for 1 investor with a billion dollars than for a million small investors. To reach the individual retail investor, advertising expenses must be incurred, sales commissions paid and frequent telephone inquiries answered. Numerous prospectuses and statements must be sent to households on a continuing basis before and after they invest. All of this increases costs. To reach an institutional investor, preparing a contract proposal and establishing an investment program are necessary, but once the contract is secured this involves large sums of assets for which only one shareholder need be served. Even if the billion dollar investor gets a higher service level than the thousand dollar investor, total demands relative to total assets are much smaller for the former. And, marginal investments by the large investor are virtually cost-free, hence the sliding scale for fees.

These factors lead to pure asset management costs for institutional investors as low as $.01-.05 \%$ for passive domestic portfolios (often this is partially covered out of securities lending operations by the investment manager) and $.25-.55 \%$ for actively managed portfolios, plus another .03-.1\% for brokerage fees and internal administrative costs that are associated with asset management. This brings the total cost to $.04-.65 \%$, depending on asset category and investment strategy chosen (see Tables 12 and 19). These would be the costs in a centrally managed funded social security pillar without IA's.

\section{Capturing the Benefits of Institutional Rates for a Mandatory IA System}


Mandatory IA systems can also be structured to obtain scale economies in asset management without high marketing costs. In other words, they can offer workers an opportunity to invest at much lower cost than would be possible on a voluntary basis. Accomplishing this requires centralized collections and constrained worker choice-- to gain the advantages of bulk buying power and diminished impetus for marketing. Still, enough choice could be retained to satisfy individual preferences and avoid political control. Such constrained choice is alternative 2 .

Specifically, contributions could be collected together with social security payroll taxes or income taxes, through a public agency or private clearinghouse. These intermediaries would then allocate the funds according to worker choice, among a limited number of money managers chosen in a competitive bidding process.

Centralized collection "piggybacking" on existing tax agencies involves long delays, as much as 1-2 years, before the worker's contribution is allocated to his account and money manager. It may not be an option for countries that have weak tax collection mechanisms and distrust of public agencies. In these countries workers may be more likely to contribute if they can put the money directly into their own accounts. This was the case, for example, in Chile at the time of its reform; a retail approach was the only feasible approach under those circumstances. Piggybacking, however, can greatly reduce collection costs as well as facilitate compliance and record-keeping (see Part V) in countries that have the capacity. Moreover, because the contributions are aggregated, opportunities exist for reducing marketing costs associated with asset management and increasing the bargaining power of investors.

The exact number of money managers to be used would depend on the inflow of contributions relative to the size of the cost-minimizing assignment per manager. The strength of the country's desire to give workers choice would be an additional factor. Initially the number might range from 2-3 in countries with a small contribution base to 5-10 in larger countries, chosen in a competitive bidding process. This number would gradually increase; with the growth of assets in the system. Issues related to the bidding process include: selection criteria, whether to hire the "best" bidder for each category or all firms that bid better than a stipulated threshold; term of contract and frequency of re-bidding; and fee structure (performance-based, asset-based, or otherwise). For countries with weak financial markets, an auction would provide an incentive - a guaranteed or quasi-guaranteed market share--for international companies with 
financial expertise to enter the industry. To produce this outcome, these countries would need to avoid the temptation for corruption and political manipulation of the bidding process.

Initially the options might be restricted to a variety of passive investment choices indexed to different diversified benchmarks. Again, this may not be feasible or desirable in developing countries where such benchmarks do not exist, where the rapid entry of new firms make it difficult to build a stable benchmark, and where inefficient markets give an edge to active managers who can obtain private information. But where they are feasible, the bidding process and passive investment strategies would help avoid high start-costs and large expense deductions from small accounts.

Later, as aggregate assets increase, entry could be opened up to a larger number of money managers, including active managers who agree to operate below a specified price ceiling. The ceiling would be set high enough to cover marginal cost plus part of fixed costs but low enough to discourage marketing expenses. It might vary according to benchmark chosen: higher for small caps and emerging market portfolios than for domestic large caps. For example, the ceiling might be set at the mean or median money management cost, by asset class, of the largest pension funds in the country, with record-keeping and shareholder servicing provided elsewhere (see Table 12 and Part V). Alternatively, it might be performance-based around this mean or median.

The Swedish system of centralized collection and negotiated fees (or a variant that replaces negotiated fees with a fee ceiling), moves directly to this second stage: it might involve most mutual funds in the country very quickly. This could add to costs faced by workerinvestors if lower fees are traded off for greater choice and if advertising explodes. The Bolivian system of auctioning off entry rights at the start is much more cautious-but of course Bolivia did not have a local mutual fund industry to start with. This scheme is also consistent with the two-tiered plan for the U.S. outlined in Goldberg and Graetz 1998. Their plan would initially give workers a choice among six index funds (SPIFs), but would allow workers to opt out into a broader set of qualified options (QPFs) once their accounts reached a specified size.

One intended consequence of this method, that accounts for much of the cost saving, is reduced marketing expenditures. Initially, limited entry and price competition in the auction process would reduce the incentive for marketing. Later, as entry increases, competition among investors would also increase but sales commissions could be prohibited or greatly diminished 
by low fee ceilings. Mass media advertising and direct mailing would probably still be used but the bidding process or fee ceilings suggested above would set a narrow limit here.

Is this attempt to reduce marketing expenses efficient? The object is to avoid expenditures on costly zero-sum game competition among investment companies, paid for by workers, when this is not serving other socially useful purposes. It seems likely that these useful purposes would be less in a mandatory IA system than in the voluntary market, for several reasons. First, the total investable amount is predetermined by law; marketing is therefore not needed to induce people to save or to invest in financial markets. Second, mandatory centralized collections can aggregate savings into large blocs for efficient investment without marketing expenses. Third, information is imparted by marketing, but investment companies and brokers have a clear incentive to impart misleading information that is in their interest rather than the consumer's interest. Broker-salesmen generally have ties to a limited number of fund families and have little incentive to recommend no-load funds to their clients even if these are the best buys. This would be a problem especially in a new mandatory system with many small inexperienced investors. A mandatory IA system should include other more cost-effective ways to impart non-biased information relevant to investment choices. Marketing does provide an incentive for good performance and innovation. This, however, would be partially retained by the remaining mass advertising and by the voluntary market place.

Reducing marketing expenses may be less feasible or efficient in countries with low tax collection capacities and less public information, particularly if they wish to use marketing as a tool to increase coverage and reduce evasion. For example, Bolivia specifically built this mandate into its bidding process.

A second consequence of these economies is constrained choice. Constrained choice may increase the probability of corruption or collusion and decrease the adaptability to individual risk-return preferences--although not as much as a single centralized fund. Individuals may have a smaller sense of "ownership" and a larger sense of being taxed if their choice of investment manager is constrained. The risk to the government of being responsible for a bail-out in case of investment failure may be greater when it has "endorsed" or participated in the process of choosing a small number of asset managers. The constraint on choice and these consequent dangers would be particularly great in countries with a small contribution base and a tradition of inefficient government control. Greater choice could be allowed, and hence the 
trade-off between low cost and low political risk would be less serious, in economies with larger investable resources-from higher contribution rates or wages. As we have seen, a large country such as the U.S. could allow considerable choice and Sweden plans to allow substantial choice, even with a small contribution rate. This would be consistent with low cost so long as other mechanisms, described above, were put in place to discourage marketing expenses.

Constrained choice has an additional value at the start of a new system. It facilitates learning-by-doing, which is probably the most effective form of education, by limiting the mistakes people can make. It makes government guarantees of benefits potentially less costly by diminishing moral hazard problems. Constrained choice can represent a Pareto-improvement if these advantages, together with the real cost-reduction, are valued by participants more than the flexibility they would have had in the retail markets. This is most likely to be the case if the constraints on choice are not too great. Since some participants may prefer the lower costs while others may prefer greater choice, and compensatory payments may not be possible, distributional as well as efficiency effects are almost certain to be involved.

We estimate that asset management costs in this system of constrained choice (alternative 2) would be much less than in the retail market. They would be only slightly higher than those of a single centralized fund, due to advertising costs (Table 19). Costs of record-keeping and communicating with multiple participants $(\mathrm{R} \& \mathrm{C})$ would, however, be additional in an IA system, since numerous individual accounts, rather than one big trust fund, would have to be tracked. We move on now to discuss how this could be handled in a cost-effective manner.

\section{Record-keeping and Communications}

Money management costs to investors in an IA system can be drastically reduced by moving money in large blocs, eliminating sales commissions and using passive investment strategies. The total cost attributable to record-keeping and shareholder communication (R\&C), however, remains larger than if these services were provided for one large institution. In fact, this could be the largest cost component in a new IA system that has successfully reduced investment and marketing expenses. Most important: the magnitude of these costs and the ways in which they are covered are, to a substantial extent, a policy choice rather than an exogenously given variable. 
$\mathrm{R} \& \mathrm{C}$ costs depend mainly on the number of accounts and secondly on the level of service provided. The figures given below indicate that, under current circumstances, a fund that has an annual fee of $1 \%$ of assets must have an average account size of $\$ 2500$ simply in order to cover its $\mathrm{R} \& \mathrm{C}$ costs with that fee; if the fund is no-load and its fee $.2 \%$, as in some of the lower cost index funds, the average account size must exceed $\$ 16,500$. This immediately suggests that mutual funds would not be interested in small IA accounts, or would charge them an annual fee that far exceeds $1 \%$ of assets (thereby cutting benefits comensurably), unless some new means is developed of handling $\mathrm{R} \& \mathrm{C}$ costs. This section discusses how that might be accomplished.

How high are R\&C costs? Record-keeping alone is cheap. To illustrate: In 1995, the U.K. government contracted with Andersen Consulting to develop and operate a computerized information system for its social security programs, covering 65 million participants. The new system is just beginning to come on line, in 1998. The contract provided this system at an annual cost of less than $\$ .50$ per account. Specifically, seven years of payments will be made, at a total present value cost of 134 million pounds or $\$ 210$ million. Of this total, $40 \%$ will be paid to Andersen and $60 \%$ represents agency inputs. The cost would have been almost $\$ 1.00$ per account, except that Andersen contributed an estimated 100 million pounds in system development costs, thereby underbidding other competitors commensurately. Under the contract, Andersen will communicate only with the government, not with the 65 million participants. (For more details see Report by the Comptroller 1997).

In contrast, competition in the U.S. mutual fund industry has resulted in a high and expensive level of service that far exceeds mere record-keeping, in part because shareholder service and building shareholder loyalty (a form of marketing) are closely intertwined. Service innovations include the ability to make frequent telephone exchanges, to wire funds, to write checks, and to speak to a representative 12 or even 24 hour per day. Not only are these services available, their costs are hidden. They are free of charge to the individual user-although, of course, not to users as a group. Customers with low transactions and few communications crosssubsidize the others, thereby encouraging further use.

Technology (internet, automated phones) is ostensibly being used to reduce costs, but so far the savings have not materialized. Instead, the greatest impact has been to increase investment costs and improve service still further. Additional electronic options are available while the utilization of expensive personal services has not diminished. This helps explain why, 
in the regressions for 1992-97, a period which has seen great technological strides, expense ratios rose slightly, and total expenses (expense ratio times assets) rose dramatically. A lower service level with correspondingly lower costs may be appropriate in a mandatory IA system, especially one in which accounts are small. The competitive solution aimed at larger investors may not be socially optimal for small investors. Yet the market may not react if expensive services are preferred by the large investors who are the most profitable ones.

How much do mutual funds spend on record-keeping and shareholder communication? According to periodic surveys of transfer agents (i.e., the organizations which provide these services for mutual funds), average cost per account and per open account have been quite constant at $\$ 21$ and $\$ 25$ per account, respectively (Table 13). However, they are not uniform across all funds. They tend to be lower for funds that contract out the transfer agent function rather than performing it internally. This may result because pricing in internal arrangements is not an arms-length competitive transaction and because internal control is designed to provide more personalized service, to inculcate loyalty to the fund. Costs per account are $33 \%$ higher for money market than for equity funds, because of the greater transaction volume and check-writing facilities offered by the former. They are twice as high for direct market retail funds compared with funds that sell through brokers (\$33 versus $\$ 17)$. Brokers, of course, perform some of the customer communications functions that are otherwise provided by the fund, in exchange for their sales commissions. Transfer agent costs are $20 \%$ higher for accounts where dividends are paid monthly as compared with annually.

Each transaction has a real cost. Processing the application for a new account costs at least $\$ 5.00$; a personal telephone call costs $\$ 6.00$; check-writing costs $\$ 5.00$ to set up and $\$ 1.00$ per draft thereafter (Table 14). Despite these incremental costs for each transaction, the most common method transfer agents use for charging funds is a flat fee per account. U.S. mutual funds rarely charge shareholders special fees for checkwriting, exchanges or telephone inquiries (Table 15). This is in part due to the cost of measuring and charging for transactions, and in part to the strong desire of funds to avoid antagonizing high-asset consumers. The net result is the absence of incentives for shareholders to economize on these services and the presence of a cross-subsidy from non-users to heavy users.

How could $\mathbf{R} \& \mathbf{C}$ costs be reduced in a mandatory IA system? These numbers suggest ways in which record-keeping and communications costs could be dramatically reduced in a 
mandatory IA system. Most basically, the record-keeping and communications function could be separated from the asset management function and centralized--either in a public agency, or contracted out to an independent private company, or in a clearing-house run jointly by all participating funds. In fact, the market has been moving toward out-sourcing the transfer agent function for the mutual fund industry and concentrating it in two or three large companies. So this would merely accelerate and standardize this process.

Centralization immediately reduces system-wide costs by avoiding the set-up and systems integration problems that occur when a member switches his or her account from one fund complex to another. It keeps a single record of a worker's lifetime contributions and returns. This is particularly important in a mandatory system where such a record should be readily available, error-free, upon retirement. The separation of $\mathrm{R} \& \mathrm{C}$ from the assetmanagement function would actually increase the choice of asset managers available to small account holders, since $\mathrm{R} \& \mathrm{C}$ costs, which are relatively expensive for such accounts, would be covered elsewhere. ${ }^{7}$ It would facilitate a cross-subsidy to small accounts, which may be socially desirable, without competitive pressures that might oppose this. Moreover, centralization would allow personalized services to be reduced without generating inefficient competitive pressures to upgrade. (But note that government capacity and trust in public agencies are necessary preconditions for centralized $\mathrm{R} \& \mathrm{C}$, and these are lacking in many developing countries-see earlier comment in Part IV).

A second step concerns setting the level of basic service as well as the charges for incremental service in an unbundled system. It is not clear that consumers would willingly pay for the current level of service and personalized communications if charged directly. This would be particularly true for the small investors of a mandatory IA system rather than the relatively large investors of today's voluntary mutual fund system. The basic service level should be low enough to pass a benefit-cost test, given the small average size of the account for the first few years of the new system. It should focus on keeping accurate, timely records and processing transactions efficiently. At the same time, different service levels could be chosen by those willing to pay for more.

For example: Services such as check-writing could be ruled out; dividends and capital gains could be credited annually; fund transfers or other transactions could be restricted or discouraged by a fee that covers the cost. Most important because it is most expensive, 
personalized services, especially telephone discussions with representatives, could be minimized by encouraging members to use automated phones or the internet instead. A possible strategy here would be to make telephone service available only for limited hours per day and build in probable waiting time to encourage members to switch to automated techniques. Less palatable is the use of toll calls instead of 800 numbers to pass the phone company charges on to consumers, or the use of 900 numbers to impute the representative's time as well. Costs could be cut further by sending statements annually instead of quarterly. The costs and performance of each fund could be reported in a brief 1-2 page summary, rather than the lengthy and detailed prospectus which is required of all mutual funds today. In fact, the short statement may be more educational than the lengthy prospectus which few people read or understand. In-person workshops provided by many 401k plans would be avoided and replaced by brochures introducing investors to concepts such as risk-return trade-offs, diversification and indexing, published for mass distribution. Market competition for high income investors does not allow mutual funds to use these strategies, but centralized record-keeping in a mandatory system does. Table 16 compares the cost composition of a typical mutual fund account and a modest-service account proposed for an IA system

The \$20 account. While money management fees depend on volume of assets, R\&C fees depend on number of participants. Based on the above information and specifications, it appears that a functional service level could be delivered for an $\mathrm{R} \& \mathrm{C}$ cost of less than $\$ 20$ per account. $^{8}$ This approximates the cost per account of the transfer agent function in mutual funds where dividends are distributed annually. The potentially more difficult clientele of an IA system would be offset by the lower level of personal communications offered.

This approach would be roughly consistent with the record-keeping and communications costs of the Thrift Savings Plan (TSP) for federal employees in the U.S. The TSP began in the late 1980's. It now has 2.3 million participants and approximately $\$ 65$ billion in assets (Table 17). TSP costs for $\mathrm{R} \& \mathrm{C}$ have remained fairly stable at $\$ 19$ per account ( $\$ 22$ per active account) since 1990. Funds are invested in a variety of passively managed portfolios, so additional costs of asset management and brokerage fees are only a few basis points. (We are reporting gross costs although these are partially offset on TSP books by account forfeitures).

TSP R\&C costs are low in part because much of the communications with participants is done through the federal agencies where members are employed. In a mandatory IA system 
information would have to be distributed directly from the central clearinghouse to the individual, at some monetary cost. However, TSP provides certain expensive services that would not be included in a mandatory IA system, such as loans and withdrawals, that are difficult to process and are responsible for many of the phone calls. ${ }^{9}$ Moreover, an IA system would benefit from much greater economies of scale. For example, the TSP numbers given above include \$2-\$4 per account of fixed administrative costs that would disappear in the much larger social security system, bringing the total to less than $\$ 20$.

Table 18 converts this $\$ 20$ estimated annual $\mathrm{R} \& \mathrm{C}$ cost into an expense ratio, based on the assumption that the average worker contributes $\$ 500$ per year. In the first year, the $\$ 20$ is $4 \%$ of the worker's assets. If the real rate of return is $5 \%$, the $\mathrm{R} \& \mathrm{C}$ expense ratio falls to less than $1 \%$ by the fourth year. (If the new system were adopted in the U.S. in 1999 and a specified portion of payroll were put in escrow pending tax reconciliation and establishment of the new information system, at least three years of contributions and interest would accumulate before the IA's became operative. By that time, the $\$ 20$ charge would already be close to $1 \%$ of assets for the average worker who was there from the start). By the time the first cohort of workers retires 40 years later, it would be only 3 basis points of their assets.

Of course, each year new workers would be entering the system, beginning again with small accounts, as current workers age and retire with larger accounts. We assume that $\mathrm{R} \& \mathrm{C}$ charges will be based on assets, hence large accounts will subsidize small accounts. In a simplified steady state with no population growth or wage growth, and with $5 \%$ real interest, the average account size will be $\$ 21,927$ and the $\$ 20$ charge for record-keeping and communications expenses is equivalent to 9 basis points, or $2 \%$ of foregone retirement benefits.

After adding these 9 basis points to the cost of asset management derived in the previous section, the total cost for an IA system based on constrained choice is projected to be .14-.18\% if passively managed, or .49-.79\% if actively managed. In constant dollars, the steady state cost for the average size account, if passively managed, would be \$31-39. This cost is much lower than an IA system run through the retail market. It is lower than individual investors have access to in the voluntary market, primarily due to reduced marketing costs and secondarily because of bulk buying power and no-frills service-but at the price of less choice. ${ }^{10}$ It is slightly more than a single centralized fund would cost, but offers much greater adaptability to individual preferences and insulation from political risk in exchange (Table 19). 


\section{Conclusion}

We started this paper by asking: what is the most efficient way to set up an IA component of a social security system, and how do we compare the cost effectiveness of investing social security funds through 1) the retail market with open entry and choice, 2) the institutional market with constrained choice among investment companies and 3) a centralized fund without IA's or choice?

The evidence in this paper demonstrates that large cost savings can be realized by investing IA's through the institutional market with constrained choice. This would involve centralizing collections, record-keeping and communications and moving money in large blocs rather than as small individual investments, while still giving workers considerable choice among asset managers. This can be accomplished initially through a competitive bidding process in which a limited number of managers are chosen for differentiated portfolios, and subsequently through an open entry process in which companies agree to restrict their fees in exchange for the right to participate. The cost savings to participants come largely from efficiency gains - exploiting economies of scale in asset management, avoiding duplicate collection systems and fragmented record-keeping systems, reducing marketing expenses, and providing incentives to economize on communication costs. A smaller part of the savings is due to greater bargaining power about the distribution of fixed costs between the mandatory and voluntary markets. Employing passive managers in the early phase would further reduce costs.

While these recommendations for reducing costs hold for industrialized countries, they may have to be modified for developing countries. On the one hand, these countries tend to have weak tax collection mechanisms, distrust of government's ability to handle the record-keeping and bidding processes effectively, and inefficient markets that make passive investing more problematic. On the other hand, the low incomes and contribution bases of many of these countries make it all the more advantageous to limit entry through an auction in order to benefit from scale economies and avoid high start-up marketing costs. A separate paper will deal with these issues in greater detail.

The evidence indicates that many of the same factors that reduce costs will also raise returns. The price paid for constrained choice relative to open choice in the retail market is 
therefore not lower expected returns, but rather other less quantifiable factors such as greater risk of corruption, collusion and a weaker sense of worker ownership. The importance of these factors will vary among countries and will decrease as the number of asset managers in the system increases. A contribution base that is large enough to allow meaningful choice among multiple asset managers will go far toward diminishing these dangers.

As to the relative cost effectiveness of a constrained IA system versus a centralized fund with no choice, we have seen that the extra costs associated with IA are negligible, providing a modest level of service is chosen for record-keeping and communicating with participants. At the same time, optional services might be unbundled so that those who use them pay for them.

The most expensive service involves communication and education. It is difficult to expect consumers to make complicated financial choices without information. Our $\mathrm{R} \& \mathrm{C}$ cost estimate included an allocation for preparing and distributing published materials. However, we would argue that, especially for workers who are saving for the first time in their lives, the best education comes from practice-with small amounts. This is another reason for simplifying and limiting choice, especially at the beginning of the new system. By the time greater choice is permitted, accounts will have grown and most workers will already have learned, from experience. No doubt the popular press (newspapers, magazines, TV talk shows) would also play a significant role in educating the public, as they surely would face a huge demand once everyone had an IA.

The structure of an IA system matters. Administrative costs need not make IA's prohibitively expensive, as is sometimes claimed. The cost of managing savings in a mandatory IA system can be significantly less than the cost of voluntary saving. An IA system that gives workers choice can be structured to cost only slightly more than a single centrally managed fund with no choice. Decisions about whether to fund and whether to manage the funds publicly or privately should therefore depend on other factors, such as the economic benefits of funding and the risks and returns associated with public and private management of funds. 


\section{TABLE 1}

\section{Annual Asset-based Fee equivalent to 15\% Up-Front Fee in Chile (as percentage of assets)}

\begin{tabular}{|c|c|c|c|}
\hline Starting Age & $\begin{array}{c}\text { Contribution Made } \\
\text { For } \\
1 \text { Year Only At Given } \\
\text { Age }\end{array}$ & $\begin{array}{c}\text { Contributions Made For } 20 \\
\text { Years } \\
\text { Only, Starting At Given Age }\end{array}$ & $\begin{array}{c}\text { Contributions Made Every } \\
\text { Year } \\
\text { Until Age 65, } \\
\text { Starting At Given Age }\end{array}$ \\
\hline & 1 & 2 & 3 \\
\hline 25 & 0.43 & 0.55 & 0.73 \\
\hline 35 & 0.58 & 0.82 & 1.01 \\
\hline 45 & 0.87 & 1.59 & 1.59 \\
\hline 55 & 1.79 & & 3.37 \\
\hline 64 & 32.09 & & 32.09 \\
\hline
\end{tabular}

\section{Assumptions:}

This table shows the annual fee based on assets that will yield the same capital accumulation at age 65 as would a $15 \%$ front-loaded fee on in-coming contributions. In column 1 a single year of contributions is assumed at the starting age. In column 2 worker continues contributing a fixed percentage of wage for 20 years. In column 3 worker continues investing fixed percentage of wage from starting age until age 65. Worker contributes in monthly payments and keeps money invested in system until age 65 . Rate of return of $5 \%$ is assumed, but results are very insensitive to rate of return. For columns 2 and 3, annual wage growth of $2 \%$ is assumed. 


\section{TABLE 2}

Composition of Expenditures of Chilean AFP's, 1982-98 (as percentage of total expenditures each year)

\begin{tabular}{|c|c|c|c|}
\hline Year & Wages and Benefits & Marketing Costs * & Other \\
\hline 1982 & 25 & 46 & 29 \\
\hline 1983 & 30 & 40 & 32 \\
\hline 1984 & 32 & 36 & 37 \\
\hline 1985 & 33 & 30 & 39 \\
\hline 1986 & 37 & 24 & 41 \\
\hline 1987 & 38 & 21 & 40 \\
\hline 1988 & 37 & 23 & 39 \\
\hline 1989 & 39 & 22 & 37 \\
\hline 1990 & 39 & 24 & 37 \\
\hline 1991 & 37 & 26 & 33 \\
\hline 1992 & 34 & 30 & 31 \\
\hline 1993 & 32 & 35 & 29 \\
\hline 1994 & 31 & 38 & 26 \\
\hline 1995 & 28 & 43 & 24 \\
\hline 1996 & 25 & 49 & 25 \\
\hline 1997 & 24 & 52 & 46 \\
\hline 1998 (to June) & 30 & & 37 \\
\hline
\end{tabular}

* Includes sales commissions, advertising and amortization of start-up costs, most of which involved selling costs. Wages and benefits of regular staff involved in planning and managing the marketing effort and handling the paperwork connected with account transfers are not included here, so full costs of marketing are understated. 


\section{TABLE 3}

Characteristics of Mutual Fund Sample, 1992

\begin{tabular}{|c|c|c|c|c|c|}
\hline 1992 & \# of Funds & $\begin{array}{c}\% \text { of Total } \\
\text { Studied }\end{array}$ & \begin{tabular}{|c|} 
Assets \\
(Avg)
\end{tabular} & \begin{tabular}{|c|} 
Total Assets \\
For \\
Category \\
\end{tabular} & \begin{tabular}{|c|c|}
$\begin{array}{c}\% \text { of Total Assets } \\
\text { In Universe } \\
\text { Studied }\end{array}$ \\
\end{tabular} \\
\hline Type of Fund & & & $\begin{array}{c}\$ \\
\text { millions }\end{array}$ & $\begin{array}{c}\$ \\
\text { billions }\end{array}$ & \\
\hline Equity Funds & 634 & 49 & 568.4 & 360.4 & 49 \\
\hline Bond Funds & 673 & 51 & 558.7 & 376.0 & 51 \\
\hline Small Cap. & 76 & 6 & 224.0 & 17.0 & \\
\hline International & 75 & 6 & 454.5 & 34.0 & \\
\hline Emerging Markets & 8 & 1 & 100.7 & 0.8 & \\
\hline Index Funds & 15 & 1 & 735.2 & 11.0 & \\
\hline Institutional & 29 & 2 & 455.3 & 13.2 & 2 \\
\hline Funds with 12b1 fees & 725 & 55 & 498.4 & 361.3 & 49 \\
\hline Funds without 12b1 fees & 582 & 45 & 644.4 & 375.0 & 51 \\
\hline Funds with Floads & 647 & 50 & 591.0 & 382.3 & 52 \\
\hline Funds without Floads & 660 & 51 & 536.3 & 354.0 & 48 \\
\hline Total funds included in study & 1307 & & & 736.3 & \\
\hline
\end{tabular}

\begin{tabular}{|l|r|r|r|r|}
\hline \multicolumn{1}{|c|}{1992} & $\begin{array}{c}\text { Expense } \\
\text { Ratio }\end{array}$ & $\begin{array}{c}\text { 3 Yr Gross } \\
\text { Return }\end{array}$ & $\begin{array}{c}\text { 3 Yr Net } \\
\text { Return }\end{array}$ & $\begin{array}{c}\text { 3 Yr Standard } \\
\text { Deviation }\end{array}$ \\
\hline \multicolumn{1}{|c|}{ Type of Fund } & & & & \\
\hline Equity Funds & 1.40 & 10.18 & 8.70 & 18.12 \\
\hline Bond Funds & 0.94 & 9.85 & 8.76 & 5.91 \\
\hline Small Cap. & 1.48 & 14.58 & 13.37 & 23.00 \\
\hline International & 1.69 & 0.94 & -0.98 & 14.59 \\
\hline Emerging Markets & 1.84 & -2.14 & -4.22 & 18.09 \\
\hline Index Funds & 0.73 & 8.17 & 8.00 & 15.99 \\
\hline Institutional & 0.55 & 9.18 & 9.38 & 10.76 \\
\hline Funds with 12b1 fees & 1.32 & 10.62 & 8.21 & 11.47 \\
\hline Funds without 12b1 fees & 0.96 & 10.72 & 9.38 & 12.28 \\
\hline Funds with Floads & 1.11 & 10.65 & 7.97 & 11.37 \\
\hline Funds without Floads & 1.21 & 10.67 & 9.47 & 12.28 \\
\hline Total funds included in study & & & & \\
\hline
\end{tabular}




\section{TABLE 3}

Characteristics of Mutual Fund Sample, 1997

\begin{tabular}{|c|c|c|c|c|c|}
\hline 1997 & \# of Funds & $\begin{array}{c}\text { \% of Total } \\
\text { Studied }\end{array}$ & $\begin{array}{c}\text { Assets } \\
\text { (Avg) }\end{array}$ & $\begin{array}{c}\text { Total Assets } \\
\text { For } \\
\text { Category }\end{array}$ & $\begin{array}{c}\% \text { of Total Assets } \\
\text { in Universe } \\
\text { Studied }\end{array}$ \\
\hline Type of Fund & & & $\begin{array}{c}\$ \\
\text { millions }\end{array}$ & $\begin{array}{c}\$ \\
\text { billions }\end{array}$ & \\
\hline Equity Funds & 2089 & 49 & 840.2 & 1755.1 & 70 \\
\hline Bond Funds & 2165 & 51 & 348.4 & 754.2 & 30 \\
\hline Small Cap. & 243 & 6 & 473.4 & 115.0 & 5 \\
\hline International & 484 & 11 & 526.6 & 254.9 & 10 \\
\hline Emerging Markets & 127 & 3 & $\overline{164.6}$ & 20.9 & 1 \\
\hline Index Funds & 103 & 2 & 1358.7 & 139.9 & 6 \\
\hline Institutional & 311 & 7 & 409.8 & 127.4 & 5 \\
\hline Funds with 12b1 fees & 2613 & 61 & $\overline{438.6}$ & 1146.1 & $\overline{46}$ \\
\hline Funds without 12b1 fees & 1641 & 39 & $\overline{830.6}$ & 1363.0 & 54 \\
\hline Funds with Floads & 1483 & 35 & 705.7 & 1046.6 & 42 \\
\hline Funds without Floads & 2771 & 65 & 527.9 & 1462.7 & 58 \\
\hline Total funds included in study & 4254 & & & 2509.4 & \\
\hline
\end{tabular}

\begin{tabular}{|l|r|r|r|r|}
\hline \multicolumn{1}{|c|}{$\mathbf{1 9 9 7}$} & $\begin{array}{c}\text { Expense } \\
\text { Ratio }\end{array}$ & $\begin{array}{c}\text { 3 Yr Gross } \\
\text { Return }\end{array}$ & $\begin{array}{c}\text { 3 Yr Net } \\
\text { Return }\end{array}$ & $\begin{array}{c}\text { 3 Yr Standard } \\
\text { Deviation }\end{array}$ \\
\hline \multicolumn{1}{|c|}{ Type of Fund } & & & & 15.03 \\
\hline Equity Funds & 1.48 & 20.55 & 18.47 & 4.85 \\
\hline Bond Funds & 1.08 & 11.92 & 10.27 & 18.99 \\
\hline Small Cap. & 1.51 & 24.15 & 22.16 & 11.02 \\
\hline International & 1.64 & 12.19 & 9.95 & 19.87 \\
\hline Emerging Markets & 2.12 & -0.56 & -3.36 & 12.76 \\
\hline Index Funds & 0.66 & 22.62 & 21.74 & 9.69 \\
\hline Institutional & 0.79 & 15.72 & 14.93 & 9.63 \\
\hline Funds with 12b1 fees & 1.49 & 15.76 & 13.48 & 10.19 \\
\hline Funds without 12b1 fees & 0.93 & 16.79 & 15.61 & 9.78 \\
\hline Funds with Floads & 1.15 & 15.90 & 13.25 & 9.88 \\
\hline Funds without Floads & 1.33 & 16.30 & 14.86 & $\mathbf{9 . 8 5}$ \\
\hline Total funds included in study & $\mathbf{1 . 2 8}$ & $\mathbf{1 6 . 1 6}$ & $\mathbf{1 4 . 3 0}$ & \\
\hline
\end{tabular}




\section{$\underline{\text { Table } 4}$}

\section{Composition of Mutual Fund Expenses, 1997* \\ (in basis points)}

\section{Expenses Included in Expense Ratio}

Investment Advisor

Distributor for $12 \mathrm{~b} 1$ fees*

Transfer Agent

Other (custodial, legal, audit, etc.)

Reported expense ratio

\section{Other Expenses}

Brokerage fees paid by fund

Annualized front-loaded sales charge

paid by shareholder ${ }^{\star}$

Total expenses as \% of assets*
Simple

Average

56

35

13

23

127

26

31

185
Asset-Weighted Average Active Passive

$\begin{array}{rrr}49 & 52 & 8 \\ 21 & 22 & 2 \\ 12 & 12 & 5 \\ 9 & 8 & 13 \\ \mathbf{9 1} & \mathbf{9 5} & \mathbf{2 8}\end{array}$

12

12

3

$\begin{array}{lll}40 & 43 & 1\end{array}$

$143 \quad 150$

32

* The $12 \mathrm{~b} 1$ fee is a fee that is paid annually by the fund, primarily for distribution of new shares and related service. It is financed by a charge paid by all shareholders, whether or not they have purchased their shares through a broker. It is part of the fund's expense ratio and is based on assets. The front-loaded sales charge is paid directly to the distributor by investors who purchase through brokers, as a $\%$ of their new investment. It is not included in the fund's expense ratio. The average front-loaded fee is $4.48 \%$. It is charged by about $1 / 3$ of all funds. In this table, this one-time fee has been annualized according to the procedure described in endnote 4. These numbers are averaged over all funds, ignoring the big distinction in costs to shareholders between funds that impose sales charges and those that do not (see table 8). 
TABLE 5

Mean, Median and Standard Deviation of Variables in Sample, 1997

\begin{tabular}{|c|c|c|c|c|}
\hline & $\begin{array}{c}\text { Asset-Weighted } \\
\text { Mean }\end{array}$ & $\begin{array}{l}\text { Simple } \\
\text { Mean }\end{array}$ & $\begin{array}{l}\text { Simple } \\
\text { Median }\end{array}$ & SD \\
\hline Expense ratio (as \% of assets) & 0.91 & 1.28 & 1.17 & 0.61 \\
\hline Assets in \$billion & 9.94 & 0.59 & 0.09 & 2.35 \\
\hline \# Shareholders (in thousands) & 281.60 & 20.19 & 2.08 & 75.13 \\
\hline Assets in Family Funds (in $\$$ billions) & 151.15 & 42.06 & 12.30 & 86.00 \\
\hline 3 Year Net Return (as \%) & 20.16 & 14.30 & 11.44 & 9.22 \\
\hline 3 Year Gross Return (as \%) & 21.79 & $\begin{array}{ll}16.16 \\
\end{array}$ & 13.45 & 9.19 \\
\hline 3 Year Standard Deviation & 11.67 & 9.85 & 8.68 & 6.59 \\
\hline Turnover (as \%) & 69.40 & 98.00 & 65.00 & 117.00 \\
\hline Fundage & 19.90 & 8.97 & 5.35 & 9.58 \\
\hline \multicolumn{5}{|l|}{ Percentage of Funds That Are: } \\
\hline Bond Funds & 30 & 51 & & \\
\hline \multicolumn{5}{|l|}{ Small cap. } \\
\hline \multicolumn{5}{|l|}{ Specialty } \\
\hline International & 10 & 11 & & \\
\hline Emerging Market & 1 & 3 & & \\
\hline Institutional & 5 & 7 & & \\
\hline Index & 6 & 2 & & \\
\hline Low $12 b 1$ fee $(0.25 \%$ or less $)$ & 36 & 41 & & \\
\hline High 12b1 fee (between 0.25\% and 1\%) & 10 & 21 & & \\
\hline Front load & 42 & 35 & & \\
\hline Back Load & 12 & 27 & & \\
\hline Bank Advised & 5 & 16 & & \\
\hline
\end{tabular}




\section{TABLE 6}

\section{Determinants of Expense Ratios of Mutual Funds in the U.S., 1997 (dependent variable is total expenses/total assets, in basis points ${ }^{2}$ )}

\begin{tabular}{|c|c|c|c|c|c|c|c|c|c|c|}
\hline \multirow{2}{*}{ CORE GROUP } & \multicolumn{2}{|l|}{1} & \multicolumn{2}{|l|}{2} & \multicolumn{2}{|l|}{3} & \multicolumn{2}{|l|}{4} & \multicolumn{2}{|l|}{5} \\
\hline & & & & & & & & & & \\
\hline Intercept & 113.7 & $(59.63)^{*}$ & 112.1 & $(55.35)^{\star}$ & 111.0 & $(22.22)^{*}$ & 83.4 & $(22.03)^{*}$ & 125.0 & $(26.09)^{*}$ \\
\hline Assets in \$billion & -9.2 & $(-9.55)^{*}$ & -7.9 & $(-10.03)^{*}$ & -9.1 & $(-9.61)^{*}$ & -3.9 & $(-5.65)^{*}$ & -5.2 & $(-5.67)^{*}$ \\
\hline Asset $^{2}$ & 0.1 & $(5.22)^{*}$ & 0.1 & $(7.20)^{\star}$ & 0.1 & $(5.48)^{*}$ & 0.1 & $(-6.17)^{*}$ & 0.1 & $(4.51)^{\star}$ \\
\hline \# Shareholders in 000's & 0.1 & $(3.14)^{*}$ & & & 0.1 & $(3.02)^{x}$ & 0.0 & $(-1.48)$ & 0.0 & $(0.89)$ \\
\hline Assets/Shareholders & & & -0.4 & $(-4.9)^{x}$ & & & & & & \\
\hline Assets in Fund Complex & -0.1 & $(-7.99)^{*}$ & -0.1 & $(-7.61)^{*}$ & -0.1 & $(-8.66)^{*}$ & -0.1 & $(-7.31)^{*}$ & -0.1 & $(-10.07)^{*}$ \\
\hline 3 Year Net Return ${ }^{3}$ & -1.5 & $(-13.73)^{*}$ & & & -0.9 & $(-6.26)^{*}$ & -0.7 & $(-6.37)^{\star}$ & -0.7 & $(-4.84)^{*}$ \\
\hline \# Year Gross Return & & & -1.1 & $(-9.73)^{\star}$ & & & & & & \\
\hline 3 Year Standard Deviation & 4.6 & $(29.56)^{*}$ & 4.4 & $(27.93)^{\star}$ & 3.5 & $(14.24)^{*}$ & 3.1 & $(17.94)^{*}$ & 3.3 & $(14.32)^{*}$ \\
\hline ASSET ALLOCATION & & & & & & & & & & \\
\hline Bond & & & & & -1.9 & $(-0.52)$ & -9.6 & $(-3.71)^{\star}$ & -8.0 & $(-2.35)^{* *}$ \\
\hline Small Cap & & & & & 3.2 & $(0.76)$ & 11.6 & $(3.98)^{*}$ & -0.2 & $(0.05)$ \\
\hline Specialty & & & & & 23.0 & $(6.01)^{x}$ & 11.7 & $(4.33)^{\star}$ & 16.4 & $(4.61)^{*}$ \\
\hline International & & & & & 28.9 & $(7.61)^{x}$ & 24.1 & $(8.96)^{\star}$ & 24.5 & $(6.89)^{*}$ \\
\hline Emerging Market & & & & & 37.6 & $(5.25)^{\star}$ & 37.5 & $(7.43)^{*}$ & 39.9 & $(5.53)^{*}$ \\
\hline $\begin{array}{l}\text { INVESTMENT AND } \\
\text { MARKETING STRATEGY }\end{array}$ & & & & & & & & & & \\
\hline Institutional & & & & & & & -15.4 & $(-4.23)^{\star}$ & -52.8 & $(-11.45)^{*}$ \\
\hline Initial Investment & & & & & & & -0.4 & $(-3.22)^{*}$ & -0.4 & $(-1.9)^{* *}$ \\
\hline Index & & & & & & & -38.5 & $(-8.72)^{\star}$ & -51.7 & $(-8.86)^{*}$ \\
\hline $12 \mathrm{~b} 1$ fee $<1,>0$ & & & & & & & 18.4 & $(9.73)^{*}$ & & \\
\hline $12 b 1$ fee $=1$ & & & & & & & 43.5 & $(14.19)^{*}$ & & \\
\hline Front load & & & & & & & 2.7 & $(-1.43)$ & & \\
\hline Deferred Load & & & & & & & 47.3 & $(16.86)^{*}$ & & \\
\hline Turnover & & & & & & & 4.3 & $(8.21)^{\star}$ & 6.0 & $(8.65)^{*}$ \\
\hline Bank Advised & & & & & & & -8.1 & $(-4.44)^{*}$ & -18.7 & $(-7.88)^{*}$ \\
\hline Fundage & & & & & & & -0.2 & $(-3.26)^{*}$ & -1.1 & $(-12.37)^{*}$ \\
\hline Adjusted R2 & 23.8 & & 22.2 & & 26.9 & & 64.2 & & 37.1 & \\
\hline Dep Mean & 129.6 & & 129.6 & & 129.6 & & 129.6 & & 129.6 & \\
\hline$n$ & 3609 & & 3609 & & 3609 & & 3609 & & 3609 & \\
\hline
\end{tabular}

1. Brokerage fees and loads are not included in expense ratios.

For each equation, first column gives coefficient and second column gives t statistics

2. 1 Basis Point $=0.01 \%$

3. 3 year net returns are gross returns adjusted for expense ratio and loads

*: significant at $0.2 \%$ level

$* *$ : significant at $6 \%$ level 


\section{TABLE 7}

\section{Determinants of Expense Ratios of Mutual Funds in the U.S., 1992-1997 (dependent variable is total expenses/total assets, in basis points ${ }^{2}$ )}

\begin{tabular}{|c|c|c|c|c|c|c|c|c|}
\hline & 1 & & 2 & & 3 & & 4 & \\
\hline \multicolumn{9}{|l|}{ CORE GROUP } \\
\hline Intercept & 22.6 & $(12.73)^{*}$ & 23.0 & $(12.31)^{\star}$ & 26.4 & $(9.17)^{*}$ & 65.0 & $(31.91)^{*}$ \\
\hline Assets in \$billion & -3.5 & $(-5.97)^{*}$ & -2.2 & $(-5.97)^{*}$ & -2.7 & $(-7.05)^{*}$ & -2.3 & $(4.64)^{*}$ \\
\hline Asset $^{2}$ & 0.1 & $(5.77)^{*}$ & 1.0 & $(5.33)^{*}$ & 0.1 & $(6.18)^{*}$ & 0.1 & $(6.21)^{*}$ \\
\hline \# Shareholders & 0.03 & $(2.68)^{* *}$ & & & & & 0.0 & (1.3) \\
\hline Assets/Shareholders & & & -1.0 & $(-3.11)^{*}$ & -0.1 & $(-3.17)^{*}$ & & \\
\hline Assets in Funds Complex & -0.1 & $(-6.27)^{*}$ & -0.1 & $(-8.47)^{*}$ & -0.1 & $(-8.23)^{*}$ & -0.1 & $(-12.94)^{*}$ \\
\hline 3 Year Net Return ${ }^{3}$ & & & -0.6 & $(-16.25)^{*}$ & -0.5 & $(-13.5)^{*}$ & & \\
\hline \# Year Gross Return & -0.4 & $(-11.31)^{*}$ & & & & & -0.3 & $(-8.89)^{*}$ \\
\hline 3 Year Standard Deviation & 0.13 & $(16.79)^{*}$ & 1.5 & $(19.2)^{*}$ & 1.0 & $(-11.59)^{*}$ & 1.0 & $(12.82)^{*}$ \\
\hline \multicolumn{9}{|l|}{ ASSET ALLOCATION } \\
\hline Bond & & & & & -12.6 & $(-7.57)^{*}$ & -23.8 & $(-19.25)^{*}$ \\
\hline Small Cap & & & & & 14.9 & $(5.12)^{*}$ & 11.5 & $(6.25)^{*}$ \\
\hline Specialty & & & & & 15.7 & $(5.59)^{*}$ & 6.8 & $(3.96)^{*}$ \\
\hline International & & & & & 18.5 & $(7.65)^{*}$ & 21.7 & $(13.72)^{*}$ \\
\hline Emerging Market & & & & & 59.9 & $(12.92)^{*}$ & 48.2 & $(15.64)^{*}$ \\
\hline \multicolumn{9}{|l|}{\begin{tabular}{|l} 
INVESTMENT AND \\
MARKETING STRATEGY
\end{tabular}} \\
\hline Institutional & & & & & & & \begin{tabular}{ll|}
-15.4 \\
\end{tabular} & $(-8.09)^{*}$ \\
\hline Initial Investment & & & & & & & -0.3 & $(-2.48)^{* *}$ \\
\hline Index & & & & & & & -38.6 & $(-14.18)^{*}$ \\
\hline $12 \mathrm{~b} 1 \mathrm{fee}<1,>0$ & & & & & & & 17.7 & $(13.84)^{*}$ \\
\hline $12 \mathrm{~b} 1 \mathrm{fee}=1$ & & & & & & & 49.9 & $(23.16)^{*}$ \\
\hline Front load & & & & & & & 6.2 & $(4.71)^{*}$ \\
\hline Deferred Load & & & & & & & 49.7 & $(25.3)^{*}$ \\
\hline Turnover & & & & & & & 2.0 & $(7.46)^{*}$ \\
\hline Bank Advised & & & & & & & -2.4 & $(-1.92)^{* *}$ \\
\hline Fundage & & & & & & & -0.4 & $(-8.95)^{*}$ \\
\hline Time & 2.3 & $(11.17)^{\star}$ & 2.3 & $(10.66)^{\star}$ & 2.3 & $(10.96)^{\star}$ & 1.2 & $(6.41)^{*}$ \\
\hline
\end{tabular}

1. Brokerage fees and loads are not included in expense ratios.

For each equation, first column gives coefficient and second column gives t statistics

2. 1 Basis Point $=0.01 \%$

3. 3 year net returns are gross returns adjusted for expense ratio and loads.

*: significant at $0.2 \%$ level

$* *$ : significant at $5 \%$ level 


\section{TABLE 8}

\section{Marketing Expenses (in \%)*}

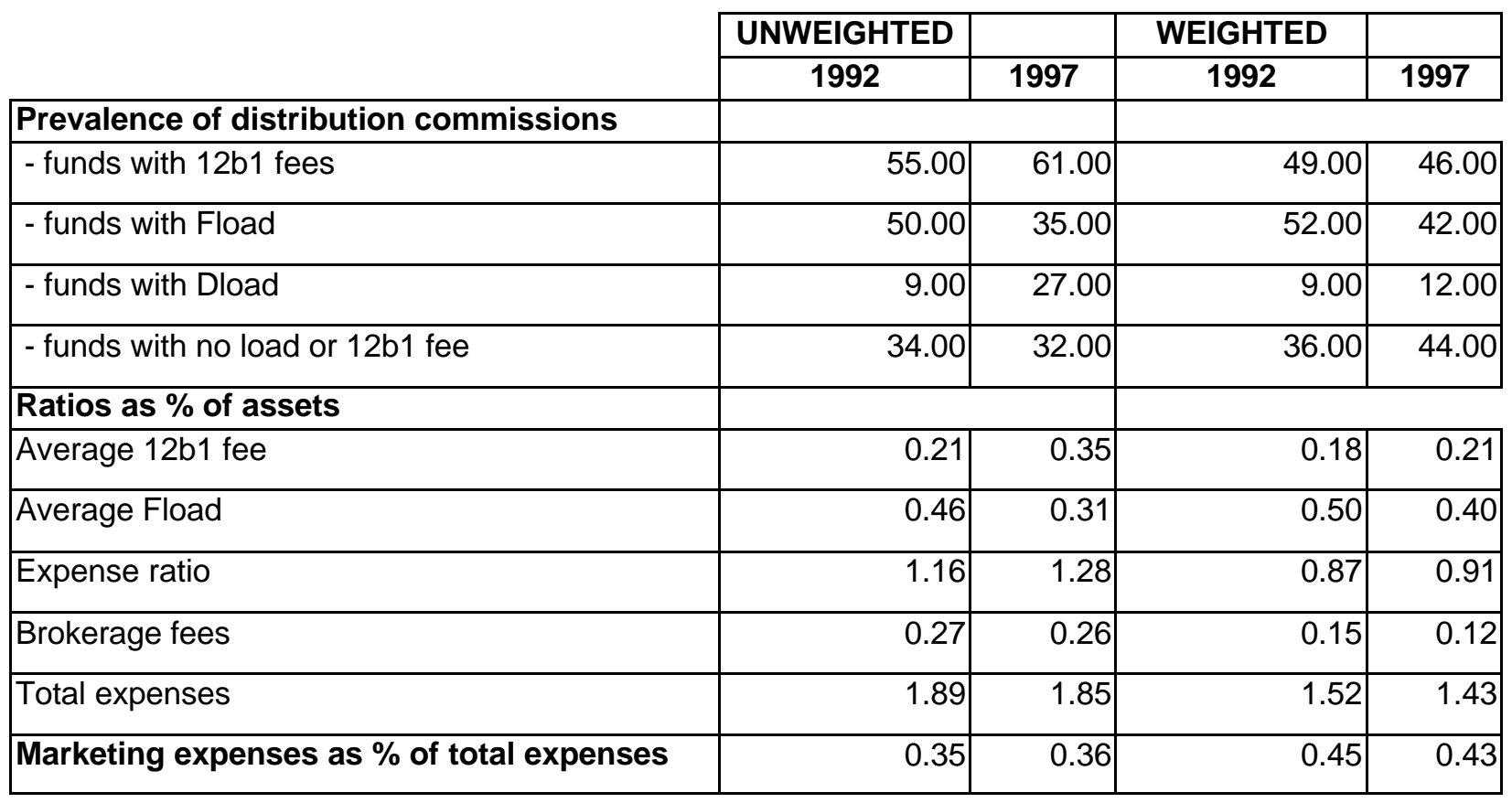

* For 12b1 fee, Fload and total expenses see Table 4 and endnote 5.

Dload is a back-loaded sales charge that is paid to the distributor by investors. Usually the Dload falls as a function of time the shares are held; therefore the average Dload paid by investors ends up being small (but we do not have precise data). Neither Fload nor Dload are included in the fund's expense ratio, since they are paid by the shareholder not the fund.

Annual marketing expenses are defined here as $12 \mathrm{~b} 1$ fee +.2 Fload .2 is annualized Fload for reasons given in endnote 5 .

If investors hold their front-loaded shares longer than assumed or if the discount rate is lower than assumed, this table overstates marketing expenses. On the other hand, given that Dload is excluded (on grounds that most people hold their investments long enough to avoid most of the Dload) and advertising costs are excluded (because they are not reported), this table probably understates marketing expenses.

Average brokerage fees are taken from a subset of funds for which they where available. 


\section{TABLE 9}

Institutional v. Retail Mutual Funds

Average Expense Ratios and Total Expense Profiles as \% of Assets, 1997*

\begin{tabular}{|c|c|c|c|c|c|c|c|}
\hline A. Expense Ratio - Unweighted & & \multicolumn{2}{|l|}{ ALL } & \multicolumn{2}{|l|}{ ACTIVE } & \multicolumn{2}{|l|}{ PASSIVE } \\
\hline & $\overline{\text { ALL }}$ & RETAIL & INSTIT. & RETAIL & INSTIT. & RETAIL & INSTIT. \\
\hline Domestic Stock Funds & 1.43 & 1.47 & 0.91 & 1.50 & 0.98 & 0.71 & 0.37 \\
\hline Domestic Bond Funds & 1.08 & 1.12 & 0.62 & 1.12 & 0.62 & 0.65 & 0.35 \\
\hline International Stock Funds & 1.69 & 1.75 & 1.09 & 1.77 & 1.15 & 0.95 & 0.66 \\
\hline Emerging Market Funds & 2.12 & 2.19 & 1.39 & 2.21 & 1.39 & 0.57 & \\
\hline All Funds in Universe & 1.28 & 1.31 & 0.79 & 1.33 & 0.81 & 0.72 & 0.42 \\
\hline
\end{tabular}

\begin{tabular}{|c|c|c|c|c|c|c|c|}
\hline B. Expense Ratio - Weighted by Assets & & \multicolumn{2}{|l|}{ ALL } & \multicolumn{2}{|l|}{ ACTIVE } & \multicolumn{2}{|l|}{ PASSIVE } \\
\hline & ALL & RETAIL & INSTIT. & RETAIL & INSTIT. & RETAIL & INSTIT. \\
\hline Domestic Stock Funds & 0.93 & 0.94 & 0.51 & 0.99 & 0.85 & 0.31 & 0.19 \\
\hline Domestic Bond Funds & 0.80 & 0.82 & 0.53 & 0.82 & 0.54 & 0.25 & 0.31 \\
\hline International Stock Funds & 1.18 & 1.19 & 0.96 & 1.20 & 0.97 & 0.42 & 0.68 \\
\hline Emerging Market Funds & 1.75 & 1.77 & 1.25 & 1.81 & 1.25 & 0.57 & 0.00 \\
\hline All Funds in Universe & 0.91 & 0.93 & 0.56 & 0.96 & 0.69 & 0.31 & 0.20 \\
\hline
\end{tabular}

\begin{tabular}{|c|c|c|c|c|c|c|c|}
\hline \multirow{2}{*}{\begin{tabular}{|l|} 
C. Total Expense Profile Including \\
Annualized Floads and Brokerage \\
Fees - Weighted by Assets \\
\end{tabular}} & \multicolumn{3}{|c|}{ ALL } & \multicolumn{2}{|l|}{ ACTIVE } & \multicolumn{2}{|l|}{ PASSIVE } \\
\hline & ALL & RETAIL & INSTIT. & RETAIL & \begin{tabular}{|l|} 
INSTIT. \\
\end{tabular} & RETAIL & INSTIT. \\
\hline Domestic Stock Funds & 1.44 & 1.47 & 0.63 & 1.55 & 0.97 & 0.35 & 0.22 \\
\hline Domestic Bond Funds & 1.30 & 1.35 & 0.65 & 1.36 & 0.65 & 0.29 & 0.34 \\
\hline International Stock Funds & 1.83 & 1.87 & 1.08 & 1.89 & 1.09 & 0.45 & 0.71 \\
\hline \begin{tabular}{|l} 
Emerging Market Funds \\
\end{tabular} & 2.29 & 2.33 & 1.37 & 2.38 & 1.37 & 0.60 & \\
\hline All Funds in Universe & 1.44 & 1.48 & 0.68 & 1.52 & 0.71 & 0.35 & 0.23 \\
\hline
\end{tabular}

\begin{tabular}{|l|r|r|r|r|r|r|r|}
\cline { 3 - 8 } \multicolumn{1}{l|}{} & \multicolumn{2}{c|}{ ALL } & \multicolumn{2}{c|}{ ACTIVE } & \multicolumn{2}{c|}{ PASSIVE } \\
\hline Domestic Stock Funds & ALL & \multicolumn{1}{c|}{ RETAIL } & INSTIT. & RETAIL & INSTIT. & RETAIL & INSTIT. \\
\hline Domestic Bond Funds & 1720 & 1597 & 123 & 1540 & 109 & 57 & 14 \\
\hline International Stock Funds & 2165 & 2014 & 151 & 1996 & 149 & 18 & 2 \\
\hline Emerging Market Funds & 367 & 331 & 36 & 323 & 32 & 8 & 4 \\
\hline All Funds in Universe & 127 & 115 & 12 & 114 & 12 & 1 & 0 \\
\hline
\end{tabular}

\begin{tabular}{|c|c|c|c|c|c|c|c|}
\hline \multirow{2}{*}{$\begin{array}{l}\text { E. Net Assets of Funds in } 1997 \\
\text { (\% of total assets) }\end{array}$} & & \multicolumn{2}{|l|}{$\mathbf{A L L}$} & \multicolumn{2}{|l|}{ ACTIVE } & \multicolumn{2}{|l|}{ PASSIVE } \\
\hline & ALL & RETAIL & INSTIT. & RETAIL & INSTIT. & RETAIL & INSTIT. \\
\hline Domestic Stock Funds & 60.3 & 95.7 & 4.3 & 89.6 & 2.1 & 6.1 & 2.2 \\
\hline Domestic Bond Funds & 30.0 & 93.2 & 6.8 & 92.0 & 6.7 & 1.2 & 0.1 \\
\hline International Stock Funds & 9.6 & 95.6 & 4.5 & 93.9 & 4.2 & 1.7 & 0.2 \\
\hline Emerging Market Funds & 0.8 & 95.6 & 4.4 & 92.4 & 4.4 & 3.3 & 0.0 \\
\hline All Funds in Universe & 100.0 & 94.9 & 5.1 & 90.7 & 3.7 & 4.2 & 1.4 \\
\hline
\end{tabular}

\footnotetext{
* International Stock Funds include Emerging Market Funds in this table.
} 
TABLE 10

Determinants of Brokerage Fees as \% of Assets (in basis points)

\begin{tabular}{|c|c|c|c|c|}
\hline & \\
\hline & $\overline{1}$ & & 2 & \\
\hline Intercept & 15.0 & $(3.09)^{*}$ & 14.0 & $(2.85)^{\star *}$ \\
\hline Assets in \$billion & -0.8 & $(-1.60)^{* \star *}$ & -0.2 & $(0.34)$ \\
\hline Asset $^{2}$ & 0.0 & (1.36) & 0.0 & $(1.99)^{* *}$ \\
\hline \# Shareholders in 000's & & & -0.1 & $(-1.59)$ \\
\hline Assets/Shareholders & -0.4 & $(-1.15)$ & & \\
\hline Assets in Fund Complex & 0.0 & $(-3.01)^{*}$ & 0.0 & $(-2.69)^{*}$ \\
\hline 3 Year Net Return & -0.5 & $(-4.03)^{*}$ & & \\
\hline \# Year Gross Return & & & -0.4 & $(-3.70)^{*}$ \\
\hline 3 Year Standard Deviation & -0.1 & $(-0.61)$ & -0.1 & $(-0.55)$ \\
\hline Bond & -13.4 & $(-4.50)^{*}$ & \begin{tabular}{l|l}
-13.2 \\
\end{tabular} & $(-4.41)^{*}$ \\
\hline Small Cap & 2.3 & (0.83) & 2.6 & $(0.94)$ \\
\hline Specialty & -2.1 & $(-0.69)$ & -1.9 & $(-0.61)$ \\
\hline International & 22.8 & $(7.34)^{*}$ & 23.6 & $(7.59)^{*}$ \\
\hline Emerging Market & 62.2 & $(11.27)^{\star}$ & 63.5 & $(11.52)^{*}$ \\
\hline Institutional & 0.9 & $(0.18)$ & 0.6 & $(0.13)$ \\
\hline Initial Investment & 0.0 & $(-0.13)$ & 0.0 & $(-0.02)$ \\
\hline Index & -4.7 & $(-0.85)$ & -5.2 & $(-0.93)$ \\
\hline $12 \mathrm{~b} 1$ fee $<$ or $=.25$ & -1.5 & $(-0.61)$ & -1.2 & $(-0.49)$ \\
\hline $12 \mathrm{~b} 1$ fee $<1,>.25$ & -23.0 & $(-5.06)^{*}$ & -22.3 & $(-4.91)^{*}$ \\
\hline Front load & -0.7 & $(-0.26)$ & 0.2 & $(0.09)$ \\
\hline Deferred Load & 20.8 & $(4.93)^{*}$ & 21.0 & $(4.99)^{\star}$ \\
\hline Bank Advised & -2.6 & $(-0.73)$ & -2.9 & $(-0.80)$ \\
\hline Turnover & 23.3 & $(17.29)^{*}$ & 0.2 & $(17.33)^{\star}$ \\
\hline Fundage & 0.2 & $(1.74)^{\star * \star}$ & 0.2 & $(-1.85)^{\star * *}$ \\
\hline Adjusted R2 & 51.0 & & 51.0 & \\
\hline $\mathrm{N}$ & 760.0 & & 760.0 & \\
\hline Dep Mean & 26.2 & & 26.2 & \\
\hline
\end{tabular}

*: significant at $.5 \%$ level

**: significant at $5 \%$ level

***: significant at $10 \%$ level 
TABLE 11

\section{Determinants of Gross and Net Returns - 1997}

\begin{tabular}{|c|c|c|c|c|}
\hline & Gross Return & & Net Return & \\
\hline Intercept & 21.18 & $(42.67)^{\star}$ & 20.51 & $(41.13)^{\star}$ \\
\hline Assets in \$billion & 0.52 & $(4.80)^{*}$ & 0.55 & $(4.98)^{*}$ \\
\hline Asset $^{2}$ & -0.01 & $(-3.38)^{*}$ & -0.01 & $(-3.50)^{*}$ \\
\hline \# Shareholders & 0.00 & $\mid(-1.01)$ & 0.00 & $\mid(-1.02)$ \\
\hline Assets in Funds Complex & 0.00 & $(0.66)$ & 0.00 & $(-1.46)$ \\
\hline Year Standard Deviation & 0.27 & $(9.98)^{*}$ & 0.24 & $(8.73)^{\star}$ \\
\hline Bond & $\mid-10.91$ & $\mid(-29.64)^{*}$ & $\mid-10.86$ & $(-29.349) *$ \\
\hline Small Cap & -2.46 & $(-5.34)^{*}$ & -2.57 & $(-5.54)^{*}$ \\
\hline Specialty & -3.51 & $(-8.28)^{*}$ & -3.65 & $(-8.57)^{\star}$ \\
\hline International & $\mid-11.58$ & $(-30.57)^{\star}$ & -11.91 & $\mid(-31.28)^{*}$ \\
\hline Emerging Market & -27.25 & $\mid(-41.59)^{*}$ & -27.84 & $(-42.29)^{*}$ \\
\hline $\mid$ Institutional & 0.73 & $\mid(1.26)$ & 0.89 & $(1.53)^{\star \star \star}$ \\
\hline Initial Investment & 0.00 & $(0.21)$ & 0.00 & $(0.70)$ \\
\hline Index & 2.84 & $(4.05)^{*}$ & 3.25 & $(4.61)^{*}$ \\
\hline $12 \mathrm{~b} 1 \mathrm{fee}<\mathrm{or}=.25$ & 0.08 & $(0.27)$ & -0.13 & $(-0.43)$ \\
\hline $12 \mathrm{~b} 1$ fee $<1,>.25$ & 0.63 & $(1.29)$ & 0.12 & $(0.24)$ \\
\hline Front load & 0.19 & $(0.63)$ & -1.32 & $(-4.35)^{\star}$ \\
\hline Deferred Load & 0.07 & $(0.15)$ & -0.59 & $(-1.32)$ \\
\hline Bank Advised & -0.54 & $\mid(-1.87)^{\star \star \star}$ & -0.43 & $(-1.49)$ \\
\hline Turnover & 0.00 & $\mid(-1.22)$ & 0.00 & $(-1.71)^{\star * *}$ \\
\hline Fundage & 0.01 & $\mid 0.53)$ & 0.01 & $(0.51)$ \\
\hline Adjusted R2 & 0.55 & & 0.58 & \\
\hline $\mathrm{N}$ & 3609.00 & & 3609.00 & \\
\hline Dep Mean & 16.33 & & 14.45 & \\
\hline
\end{tabular}

*: significant at $0.1 \%$ level

**: significant at $6 \%$ level

$* * *$ : significant at $13 \%$ level 
TABLE 12

Money Management Fees for Institutional Investors How they Vary with Amount of Investment (in basis points) ${ }^{1}$

\begin{tabular}{|l|r|r|}
\hline S + P 500 Index Mutual Fund & 10.0 & Small \& Mid cap. \\
\hline Commingled Equity Index Fund & Large cap. & 25.0 \\
\hline$<\$ 5$ million & 20.0 & 15.0 \\
\hline $5-10$ million & 10.0 & 10.0 \\
\hline $10-25$ million & 8.0 & 7.5 \\
\hline $25-100$ million & 6.0 & 5.0 \\
\hline $100-200$ million & 3.0 & 2.5 \\
\hline Balance & 1.0 & 9.1 \\
\hline Average fee for \$100 million & 7.2 & 4.3 \\
\hline Average fee for \$500 million & 2.6 & 7.0 \\
\hline Median cost-large US pens. Funds ${ }^{2}$ & 4.0 & 6.0 \\
\hline Median cost-largest US pens. Funds ${ }^{3}$ & 1.0 & \\
\hline
\end{tabular}

\begin{tabular}{|l|r|r|r|}
\hline Active Domestic Equity & Value & Growth & \multicolumn{1}{c|}{ Small Cap. } \\
\hline$<\$ 5$ million & 65.0 & 80.0 & 100.0 \\
\hline $5-25$ million & 35.0 & 80.0 & 100.0 \\
\hline Balance & 35.0 & 50.0 & 100.0 \\
\hline Average fee for $\$ 100$ million & 36.5 & 57.5 & 100.0 \\
\hline Average fee for \$500 million & 35.3 & 51.5 & 100.0 \\
\hline Median cost-large pension funds & \multicolumn{2}{|c|}{37.0} & \\
\hline Median cost-largest pension funds & \multicolumn{2}{|c|}{25.0} & 59.0 \\
\hline
\end{tabular}

\begin{tabular}{|l|r|r|}
\hline International Equity & Index & Active \\
\hline$<\$ 10$ million & 25.00 & 90.0 \\
\hline $10-25$ million & 25.00 & 70.0 \\
\hline $25-40$ million & 20.00 & 70.0 \\
\hline $40-50$ million & 20.00 & 60.0 \\
\hline $50-100$ million & 15.00 & 60.0 \\
\hline Balance & 10.00 & 60.0 \\
\hline Average fee for $\$ 100$ million & 18.75 & 66.0 \\
\hline Average fee for $\$ 500$ million & 11.75 & 61.2 \\
\hline Median cost-large pension funds & 12.00 & 54.0 \\
\hline Median cost-largest pension funds & 8.00 & 34.0 \\
\hline
\end{tabular}




\begin{tabular}{|l|r|r|}
\hline Emerging Market & Index & Active \\
\hline$<\$ 50$ million & 40 & 100 \\
\hline Balance & 40 & 80 \\
\hline Average fee for $\$ 100$ million & 40 & 90 \\
\hline Average fee for $\$ 500$ million & 40 & 82 \\
\hline Median cost-large pension funds & 23 & 77 \\
\hline Median cost-largest pension funds & 12 & 70 \\
\hline
\end{tabular}

\begin{tabular}{|l|r|r|}
\hline Fixed income & Index & Active \\
\hline$<\$ 25$ million & 12.0 & 30 \\
\hline $25-50$ million & 8.0 & 24 \\
\hline $50-100$ million & 5.0 & 17 \\
\hline Balance & 3.0 & 12 \\
\hline Average fee for \$100 million & 7.5 & 22 \\
\hline Average fee for \$500 million & 3.9 & 14 \\
\hline Median cost-large pension funds & 6.0 & 24 \\
\hline Median cost-largest pension funds & 5.0 & 25 \\
\hline
\end{tabular}

\begin{tabular}{|c|c|}
\hline $\begin{array}{l}\text { Other asset management costs for } \\
\text { institutional investors }\end{array}$ & \\
\hline Internal administrative costs: & \\
\hline - median cost-large pension funds & 6 \\
\hline - median cost-largest pension funds & 2 \\
\hline Brokerage costs: & \\
\hline - median cost-large pension funds & 10 \\
\hline - median cost-largest pension funds & 7 \\
\hline
\end{tabular}

1. Sliding scale fees for institutional commingled funds, the BT Pyramid funds, were graciously supplied by Bankers Trust, a large money manager of indexed and actively managed institutional funds. Data on large US pension funds is from: "Cost Effectiveness Pension Fund Report", prepared by CEM, 1997 for CALPERS

2. These are median costs of external money management for given type of assets, reported by 167 large US pension funds ranging in size from less than $\$ 100$ million to over $\$ 100$ billion. Median fund $=\$ 1.5$ billion. Average of 14 external money managers per fund, managing $\$ 194$ million each, median amount managed per manager $=\$ 113$ million

3. These are median costs for 10 largest US pension funds, excluding Calpers, ranging in size from \$29-65 billion. Average of 34 external money managers per fund managing \$646 million each ( $\$ 543$ million median)

4. Internal administrative costs of money management, such as executive pay, consultants, performance measurement, custodial arrangements, trustees and audits. 
TABLE 13

Transfer Agent Costs in \$'s per Account

\begin{tabular}{|l|r|r|r|}
\cline { 2 - 4 } \multicolumn{1}{c|}{} & \multicolumn{1}{c|}{1991} & 1993 & 1995 \\
\hline Cost per account & 21.55 & 22.77 & 20.93 \\
\hline - 80\% range & $\$ 8-\$ 38$ & $\$ 10-\$ 36$ & $\$ 10-\$ 32$ \\
\hline Cost per open account & 24.76 & 25.92 & 25.09 \\
\hline - if external & 23.08 & 24.56 & 23.42 \\
\hline - if internal & 25.34 & 26.39 & 25.64 \\
\hline - if equity & 20.31 & 22.52 & 21.89 \\
\hline - if money market & 31.27 & 30.28 & 28.83 \\
\hline - if sales through affiliated broker & 13.63 & 15.07 & 16.57 \\
\hline - if direct market-retail & 29.31 & 34.01 & 32.61 \\
\hline Cost per account (all) & & & 19.30 \\
\hline - if dividends paid annually & 17.12 & 20.77 & 22.29 \\
\hline - if dividends paid monthly & 23.94 & 24.94 & \\
\hline
\end{tabular}

Source: Investment Company Institute and Coopers Lybrand. Mutual Fund Transfer Agents. $1995 \& 1997$ 
TABLE 14

\section{Estimated Cost Per Transaction}

\begin{tabular}{|l|r|}
\hline Processing applications per new account & $\$ 5.00$ \\
\hline Manual transactions & $\$ 1.50$ \\
\hline Telephone calls & $\$ 2.50$ \\
\hline Personal & $\$ 6.00$ \\
\hline Automated & $\$ 1.00$ \\
\hline Correspondence & $\$ 1.50$ \\
\hline Checkwriting set-up & $\$ 5.00$ \\
\hline Checkwriting (per draft) & $\$ 1.00$ \\
\hline
\end{tabular}

Source: Data provided by State Street and by mutual fund representatives 


\section{TABLE 15}

\section{Evidence of Cross-Subsidization and Absence of Incentives to Economize}

\begin{tabular}{|c|c|c|c|c|}
\hline & 1989 & 1991 & 1993 & 1995 \\
\hline \multicolumn{5}{|c|}{$\%$ transfer agents charging mutual fund: } \\
\hline Flat fee per account & 46 & 48 & 52 & 56 \\
\hline Flat plus transaction & 30 & 24 & 15 & 12 \\
\hline Asset-based & 0 & 4 & 8 & 9 \\
\hline Other & 24 & 24 & 25 & 23 \\
\hline \multicolumn{5}{|c|}{ Composition of charges (as \%of total fee) } \\
\hline Basic fee & 67 & 78 & 77 & 79 \\
\hline Transaction + other & 33 & 22 & 23 & 21 \\
\hline
\end{tabular}

\begin{tabular}{|l|r|r|}
\hline \% Complexes charging shareholders fee for: \\
\hline & $\%$ & Fee (\$) \\
\hline Account Maintenance & 2.9 & 11.00 \\
\hline Checkwriting & 4.4 & 7.33 \\
\hline Exchanges & 2.9 & 8.75 \\
\hline Low Balance & 17.4 & 13.08 \\
\hline Transcript & 28.4 & 12.89 \\
\hline Wire & 45.6 & 7.44 \\
\hline IRA & 80.6 & 13.19 \\
\hline
\end{tabular}

Source: Investment Company Institute and Coopers Lybrand. Mutual Fund Transfer Agents. $1995 \& 1997$ 


\section{TABLE 16}

\section{Hypothetical Annual Cost per Account of Record Keeping and Service to Members (as percentage of assets)}

\begin{tabular}{|l|r|r|}
\cline { 2 - 3 } \multicolumn{1}{l|}{} & $\begin{array}{c}\text { Typical Direct Market } \\
\text { Mutual Fund (in \$) }\end{array}$ & $\begin{array}{r}\text { IA System with Central } \\
\text { Clearinghouse (in \$) }\end{array}$ \\
\hline Account set up (annualized) & 1.00 & 0.05 \\
\hline Annual record keeping and up-date & 1.00 & 1.00 \\
\hline Personal phone calls ${ }^{2}$ & 6.00 & 2.00 \\
\hline 2 automated phone calls per account & 2.00 & 2.00 \\
\hline 4 quarterly statements & 6.00 & 1.50 \\
\hline 1 annual statement or tax statement & 1.50 & $5.00^{3}$ \\
\hline 2 transactions with written confirmation & 5.00 & $1.00^{4}$ \\
\hline 1 dividend + capital gains distribution with statement & 2.50 & $1.00^{5}$ \\
\hline Distribution of prospectus and annual report & 2.50 & - \\
\hline Queries and mailing about other funds in complex & 2.50 & \\
\hline General educational material & & \\
\hline Total & 30.00 & 16.05 \\
\hline
\end{tabular}

Source: State Street mutual fund representatives and authors' own calculations.

1. We assume that the investor switches to a new mutual fund every 7 years but would stay in a centralized clearinghouse of an IA system for 40 years.

2. We assume 1 phone call per year per account in mutual fund, $1 / 3$ per account in IA system.

3. Possible fee for additional transactions.

4. Dividends and capital gains are credited to account in IA system and are included in annual statement.

5. 2 page statement substitutes for prospectus. 


\section{TABLE 17}

\section{Administrative Costs of Thrift Saving Plan 1988-98}

\begin{tabular}{|c|c|c|c|}
\hline Year & Expense Ratio (in basis points) & Average Size Account (in 000\$'s) & \$ Cost per Account \\
\hline 1988 & 67 & 6.1 & 41 \\
\hline 1989 & 43 & 8.0 & 34 \\
\hline 1990 & 26 & 9.5 & 25 \\
\hline 1991 & 23 & 10.7 & 25 \\
\hline 1992 & 20 & 12.3 & 25 \\
\hline 1993 & 16 & 14.4 & 23 \\
\hline 1994 & 13 & 16.5 & 21 \\
\hline 1995 & 11 & 20.1 & 22 \\
\hline 1996 & 10 & 23.5 & 24 \\
\hline 1997 & 9 & 28.8 & 26 \\
\hline $1998\left(^{*}\right)$ & 8 & 27.4 & 22 \\
\hline
\end{tabular}

(*) Based on Jan.-Aug., annualized

Source: Thrift Saving Plan publications and personal communications

Approximately $80-90 \%$ of these costs $(\$ 18-\$ 20$ per account) are connected with record-keeping and member inquiries, that increase with number of participants. The remaining 10-20\% (\$2-\$4 per account) are fixed costs (audits, legal expenses, trustee expenses, consultants) whose total do not vary with number of participants. These costs will fall per account as number of accounts grows. 
TABLE 18

Annual Costs as \% of Average Account over Time (*)

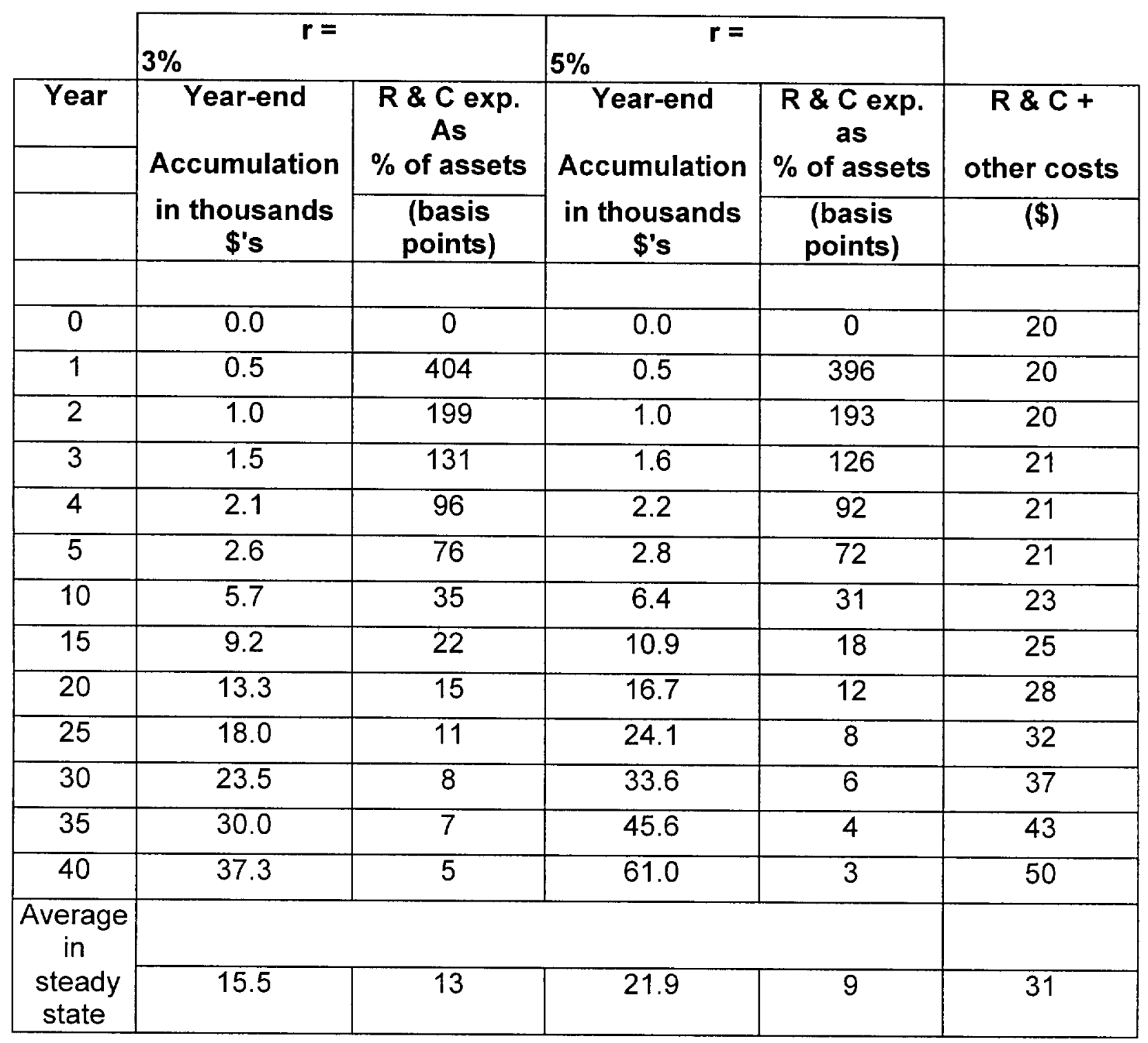

$\left.{ }^{*}\right)$ Assumptions: $\$ 500$ is contributed each year. Record keeping and communication ( $\mathrm{R}$ $\& \mathrm{C}$ ) costs are $\$ 20$ per account

"Other costs" are money management, brokerage costs and marketing expenses for large cap index funds, estimated to be 5 basis points (see Tables 12 and 19). "Other costs" would be 40 - 70 basis points for actively managed funds (see Table 19).

"R\&C + other costs" are calculated for assets accumulated if $r=5 \%$. 
TABLE 19

\section{Costs of Retail, Institutional and Constrained Choice Compared (in basis points)}

\begin{tabular}{|l|c|c|c|c|c|c|}
\cline { 2 - 7 } \multicolumn{1}{c|}{} & \multicolumn{2}{c|}{ Retail } & & Institutional & & \multicolumn{2}{c|}{ Constrained Choice } \\
\cline { 2 - 7 } \multicolumn{1}{c|}{} & Passive & Active & Passive & Active & Passive & Active \\
\hline Asset management & 8 & 52 & $1-5$ & $25-55$ & $1-5$ & $25-55$ \\
\hline Marketing & 3 & 65 & - & - & 1.0 & 5 \\
\hline R \& C & 5 & 12 & - & - & 9 & 9 \\
\hline Brokerage fee and other & 16 & 20 & 3 & 10 & 3 & 10 \\
\hline Total cost & $\mathbf{3 2}$ & $\mathbf{1 5 0}$ & $\mathbf{4 - 8}$ & $\mathbf{3 5 - 6 5}$ & $\mathbf{1 4 - 1 8}$ & $\mathbf{4 9 - 7 9}$ \\
\hline \$ cost per average account & & & & & & \\
\hline in steady state & $\$ 70$ & $\$ 329$ & $\$ 9-18$ & $\$ 77-142$ & $\$ 31-39$ & $\$ 106-172$ \\
\hline
\end{tabular}

Retail costs are taken from Table 4.

Institutional costs are from Table 12.

Constrained choice costs are from Table 12 and 18

Advertising costs under constrained choice are based on assumption that fee ceilings or bidding process will keep them low. 


\section{Endnotes}

${ }^{1}$ We concentrate on the asset accumulation phase, since annuities pose a host of other issues. We do not include the cost of PAYG schemes in this analysis since (unlike transfer systems) funded schemes either represent additional saving or diversions from other savings that would have incurred costs. Well-managed funded schemes cost more than well-managed PAYG schemes because they provide an additional service-the management of savings. Savings provide productive value to the economy that we do not get from PAYG schemes and some of this value is passed on to workers in the form of higher retirement benefits than they could get from the same contribution to a PAYG scheme. This paper is about how to manage those savings, not about whether or not to save.

2 A centralized fund has just been established in Canada, except that the government sets a defined benefit instead of a rate of return. In the U.S., which is now debating the issue, opinion is divided between those who want to follow the Canadian example in a pure DB system and those who prefer worker choice in a partial DC IA system.

${ }^{3}$ The recent spate of mergers in Chile, has decreased the number of AFP's from 21 in the early 1990's to eight currently. In Argentina the number has fallen from 25 to 16 and will probably fall further. This suggests the market is gradually responding to economies of scale-as in the U.S. mutual fund industry.

4 These fees cover most expenses of asset management, marketing and record-keeping, plus AFP profits. They do not include brokerage fees, which are covered by the AFP's and reduce their profits.

5 Average brokerage costs were estimated on the basis of a subset of funds that reported these data for 1997. The unweighted and weighted averages were 26 and 12 basis points, respectively.

Annualized front-loaded sales commissions were estimated as .2 time the front-loaded commission on new sales. An annualization factor of .2 was used to convert a one-time fee into its annual present-value equivalent, assuming that the average investment is kept in the fund for 7 years and the discount rate is $10 \%$. A high discount rate is used because the alternative for these investors may be an additional mutual fund purchase, over a period in which the 3-year asset-weighted net return was $20 \%$. The annualization factor and annualized fee are not very sensitive to the discount rate; a discount rate of $5 \%$ would have made a difference of only 3 basis points.

The 7-year average holding period is a guestimate, since good data are not available on this variable. A sample of redemption rates for equity funds purchased in 1974 showed that $50 \%$ of original shares were sold within 5 years and $76 \%$ within 15 years, which is roughly consistent with our 7 year assumption. (Wyatt Company 1990). However, the mutual fund industry and its clientele have changed substantially since 1974 so it is likely that redemption behavior has also changed. An average holding period of 10-12 years would have reduced the annualized fee by 510 basis points, while an average 5 year holding period would have increased it by a similar amount. 
Holding periods and therefore annualization factors may vary among funds. For example, evidence suggests that loads discourage movements out of funds so the holding periods of funds with loads may be higher than average (Ippolito 1992 and Chordia 1996). However, we did not have the disaggregated data that would allow us to take these differences into account.

Back-loaded sales charges are omitted from this calculation because they fall as a function of time the shares are held. Investors self-select into funds with back-loads if they expect to hold their shares for long periods. The average Dload paid for assets held more than 5 years is negligible and we do not have a more detailed distribution of holding periods. This omission slightly understates total costs.

The total fund expense profile calculated here is very similar to the total shareholder cost ratio calculated by Rea and Reid 1998, although they use slightly different datasets and definitions. The most important differences are that they deal only with equity funds (which are more expensive than bond funds) and they do not include brokerage fees in their measure, probably because they are interested in changes through time and data on brokerage fees were not reported before 1996. These two effect may cancel themselves out, in terms of a comparison with our numbers. Their simple average cost ratio is $1.99 \%$ and their asset-weighted average is $1.44 \%$, which is very similar to our numbers of $1.85 \%$ and $1.43 \%$, respectively. According to their calculations, marketing fees are $40 \%$ of total costs, while in our calculations (which include brokerage costs in the denominator) the simple avererage is $36 \%$ and the weighted average is $43 \%$.

6 The no-load is T. Rowe Price. The four companies that deal through brokers and other intermediaries are Franklin Resources, Eaton Vance, Waddell and Reed and Alliance Capital. Other publicly traded management companies are conglomerates whose money management functions are not separated from their other businesses, in their financial reports.

${ }^{7}$ For the small IA system currently under consideration in the U.S., average mutual fund fees of $1 \%$ would not cover the real marginal $\mathrm{R} \& \mathrm{C}$ cost of the bottom half of the worker population for more than 5 years. Fees in low priced index funds would not cover these costs for more than 20 years. So, these funds or their counterparts are unlikely to serve as asset managers for small accounts if the $\mathrm{R} \& \mathrm{C}$ function is decentralized. They might, however, welcome their asset management business if $\mathrm{R} \& \mathrm{C}$ is carried out and paid for elsewhere. Also see endnote 10.

8 This $\$ 20$ figure is an estimate of what a modest R\&C service package would cost, based on actual TSP costs and transfer agent costs. In contrast, the $\$ 50$ number in Diamond 1998 is Diamond's estimate of the political equilibrium, under the assumption that political pressures will drive up service levels and costs. While we do not try to estimate a political equilibriumwhich is highly subjective-it should be noted that the equilibrium service level and cost can be influenced by process and disclosure. For example, if the charge is prominently displayed on the annual statement, if the basic service is financed by cross-subsidization from large to small accounts via an asset-based fee, and if services are unbundled so that incremental services are paid for by the user, the political equilibrium may result in a relatively small common service charge. 
Also, Diamond's $\$ 50$ may include some of the costs we cover in a different category. Our total dollar cost for an average account in steady state, including money management and brokerage fees which are tied to money management, is \$29-\$37 for passive management and \$96-\$162 for active management. These costs would hold when the average account size is $\$ 21,900$ (in 1999 dollars).

${ }^{9}$ One factor that keeps TSP costs low is the absence of an 800 number for personalized phone calls. Member can call, but must pay the long distance toll charges themselves. On these terms, TSP receives about 1 personalized phone call for every two members per year, many of them in connection with loans and withdrawals.

${ }^{10}$ It may be useful to compare the cost of passive management under constrained choice with the cost of the S\&P index funds offered by Vanguard and Fidelity to individuals and institutions. These are among the lowest cost mutual funds available, marketing themselves to a costconscious clientele and making business strategy and cost allocation decisions accordingly. Their marketing expenses are kept low by the absence of $12 \mathrm{~b} 1$ fees, front loads or back loads. The Vanguard institutional fund has a 6 basis point expense ratio and we impute 3 basis points in brokerage fees, bringing the total cost to 9 basis points. The Vanguard and Fidelity S\&P index funds have an expense ratio of 19 basis points plus an imputed 3 basis points for brokerage fees, bringing the total to 22 basis points. (Actually, Fidelity's fees are higher but fees above 19 basis points have been waived to enable them to compete with Vanguard. Asset management for Fidelity's index fund has been contracted out to Banker's Trust for less than 1 basis point).

In contrast, for an IA system under constrained choice we have estimated a cost of 14 basis points for passive management of large cap stocks, including brokerage fees. The IA system would be 5 basis points more expensive than the institutional fund because of the greater recordkeeping and communications costs associated with numerous individual accounts. The IA system would be 8 basis points cheaper than the index funds for individual investors because of the lower level of service provided by centralized $\mathrm{R} \& \mathrm{C}$, the spreading of fixed costs across a larger asset base, and the bulk buying power of large money blocs.

Importantly, for the first 15 years of the IA system most accounts will be below the $\$ 10,000$ minimum investment required by Fidelity and Vanguard for these funds. This minimum investment was set by Fidelity and Vanguard precisely because of the $\mathrm{R} \& \mathrm{C}$ cost per account, discussed in the text. Smaller investors are either excluded or required to pay an additional \$10 fee, equivalent to another 10-100 basis points depending on account size, to help cover R\&C. In getting access to a similar index fund without this fee, small investors thus have an investment opportunity under a constrained choice IA system with centralized $\mathrm{R} \& \mathrm{C}$ that they did not have, or that would have been much more expensive for them, in the retail market. 
Bibliography

Baumol, William J., Stephen M. Goldfeld, Lilli A. Gordon and Michael F. Koehn. 1990. The Economics of Mutual Fund Markets: Competition Versus Regulation. Boston, MA: Kluwer Academic Publishers.

Capon, Noel, Gavan J. Fitzsimmons and Russ Alan Prince. 1996. "An Individual Level Analysis of the Mutual Fund Investment Decision." Journal of Financial Services Research 10: 59-82.

Carhart, Mark M. 1997. "On Persistence in Mutual Fund Performance." Journal of Finance 52(1): 57-82.

Chance, Don M. and Stephen P. Ferris. 1991. "Mutual Fund Distribution Fees: An Empirical Analysis of the Impact of Deregulation." Journal of Financial Services Research 5: 25-42.

Chordia, Tarun 1996. "The Structure of Mutual Fund Charges." Journal of Financial Economics 41: 3-39.

Collins, Sean and Phillip Mack. 1997. "The Optimal Amount of Assets under Management in the Mutual Fund Industry." Financial Analysts Journal 53(5): 67-73.

Dermine, Jean and Lars-Hendrik Röller. 1992. "Economies of Scale and Scope in French Mutual Funds." Journal of Financial Intermediation 2: 83-93.

Diamond, Peter. 1998. "Administrative Costs and Equilibrium Charges with IA's." NBER Conference on Administrative Costs. Cambridge, MA.

Elton, E.J., M.J Gruber, S. Das, M. Hlavka. 1993. "Efficiency with Costly Information: A Reinterpretation of Evidence from Managed Portfolios." The Review of Financial Studies 6(1): $1-22$

Ferris, Stephen P. and Don M. Chance. 1987. "The Effect of 12b-1 Plans on Mutual Fund Expense Ratios: A Note." Journal of Finance 42(4): 1077-1082.

Goldberg, Fred T. Jr. and Michael Graetz. 1998 "Reforming Social Security: How to Implement A Practical and Workable System of Personal Retirement Accounts." NBER Conference on Administrative Costs, Cambridge MA.

Gruber, Martin J. 1996. "Another Puzzle: The Growth of Actively Managed Mutual Funds." Journal of Finance 51(3): 783-810.

Ippolito, Richard A. 1992. "Consumer Reaction To Measures of Poor Quality: Evidence from the Mutual Fund Industry." Journal of Law and Economics 35:45-70. 
Kihn, John. 1996. "To Load or Not to Load? A Study of Marketing and Distribution Charges of Mutual Funds." Financial Analysts Journal 52(3): 28-36.

Lipper, Michael. 1994. "The Third White Paper: Are Mutual Fund Fees Reasonable?" New York, NY: Lipper Analytical Services.

Livingston, Miles and Edward S. O'Neal. 1996. "Mutual Fund Brokerage Commissions." Journal of Financial Research 19(2): 273-292.

McLeod, Robert W. and D. K. Malhotra. 1994. "A Re-Examination of the Effects of 12b-1 Plans on Mutual Fund Expense Ratios." Journal of Financial Research 17(2): 231-240.

Malhotra. D.K. and Robert W. McLeod. 1997. "An Empirical Analysis of Mutual Fund Expenses." Journal of Financial Research 20(2): 175-190.

Malkiel, Burton G. 1995. "Returns from Investing in Equity Mutual Funds 1971 to 1991." Journal of Finance 50(2): 549-572.

Muralidhar, Arun S. and Robert Weary. "The Greater Fool Theory of Asset Management or Resolving the Active-Passive Debate." WPS98-020. Washington DC: The World Bank.

O'Neal, Edward S. 1998. "Mutual Fund Load Structures and Adverse Dealer Incentives." Washington, DC: U.S. Securities and Exchange Commission, mimeo.

Patel, Jayendu, Richard J. Zeckhauser and Darryll Hendricks. 1994. "Investment flows and performance: evidence from mutual funds, cross-border investments, and new issues." In Ryuzo Sato, Richard M. Levich, and Rama V. Ramachandran, eds., Japan, Europe, and International Financial Markets: Analytical and Empirical Perspectives. New York, NY: Cambridge University Press.

Rea, John D. and Brian K. Reid. 1998. "Trends in the Ownership Cost of Equity Mutual Funds." Perspective 4: 1-15. Washington, DC: Investment Company Institute.

Report by the Comptroller and Auditor General. 1997. "The Contract to Develop and Operate the Replacement National Insurance Recording System." London: National Audit Office. HMSO.

Shukla, Ravi K. and Gregory B. van Inwegen. 1995. "Do Locals Perform Better Than Foreigners?: An Analysis of UK and US Mutual Fund Managers." Journal of Economics and Business 47: 241-254.

Sirri, Erik R. and Peter Tufano. 1993. "Competition and Change in the Mutual Fund Industry." In Samuel B. Hayes III, ed., Financial Services: Perspectives and Challenges. Boston, MA: Harvard Business School Press.

Sirri, Erik R. and Peter Tufano. 1997. "Costly Search and Mutual Fund Flows," mimeo. 
Trzcinka, Charles and Robert Zweig. 1990. "An Economic Analysis of The Cost and Benefits of S.E.C. Rule 12b-1." Monograph Series in Finance and Economics. New York, NY: Salomon Brothers Center for the Study of Financial Institutions, New York University.

Wyatt Company. 1990. "Investment Company Persistency Study Conducted for the National Association of Securities Dealers." 